\title{
Heavy Metals Contamination of River Water and Sediments in The Mangrove Forest Ecosystems in Bangladesh: A Consequence of Oil Spill Incident
}

Tasrina Rabia Choudhury ( $\nabla$ tasrina.rabia@gmail.com)

Bangladesh Atomic Energy Commission https://orcid.org/0000-0001-6717-2550

Thamina Acter

East-West University

Nizam Uddin

Daffodil International University

Masud Kamal

Bangladesh Atomic Energy Commission

A.M. Sarwaruddin Chowdhury

Dhaka University

M. Safiur Rahman

Bangladesh Atomic Energy Commission

\section{Research Article}

Keywords: Sundarbans, lead, chromium, water quality index, metal pollution index, enrichment factor, geo-accumulation

Posted Date: February 15th, 2021

DOI: https://doi.org/10.21203/rs.3.rs-164143/v1

License: () (7) This work is licensed under a Creative Commons Attribution 4.0 International License. Read Full License

Version of Record: A version of this preprint was published at Environmental Nanotechnology, Monitoring \& Management on December 1st, 2021. See the published version at https://doi.org/10.1016/j.enmm.2021.100484. 


\section{Abstract}

Oil spillage is one of the common pollution events of global water-soil ecosystems. A comprehensive investigation on heavy metals pollution of surface water and sediments was conducted after oil spill incident in Sela River and its tributaries of the Sundarbans mangrove forest ecosystems, Bangladesh. Water and sediment samples were collected from the preselected sampling points in Sela River, and the elemental ( $\mathrm{Pb}, \mathrm{Cd}, \mathrm{Cr}, \mathrm{Co}, \mathrm{Cu}, \mathrm{Ni}, \mathrm{Fe}, \mathrm{As}, \mathrm{Hg}, \mathrm{Mn}, \mathrm{Zn}, \mathrm{Ca}, \mathrm{Mg}, \mathrm{Na}$, and $\mathrm{K}$ ) analysis was done using atomic absorption spectrometer (AAS). This study revealed that the descending order for the average concentration of the studied elements were found to be $\mathrm{Mg}>\mathrm{Co}>\mathrm{Na}>\mathrm{Ni}>\mathrm{K}>\mathrm{Ca}>\mathrm{Pb}>\mathrm{Fe}>\mathrm{Mn}>\mathrm{Cr}>\mathrm{Cd}>\mathrm{Zn}>\mathrm{Cu}$ respectively, while As and $\mathrm{Hg}$ in water samples were found to be below detection limit (BDL). However, some of the toxic elements in the Sela River water samples were exceeded the permissible limit set by the World Health Organization (WHO) with a descending order of $\mathrm{Co}>\mathrm{Cd}>\mathrm{Pb}>\mathrm{Ni}$ respectively. Based on the water quality index (WQI), metal pollution index (MPI), and metal quality index (MI), the Sela River water is not suitable for drinking but may be used for irrigating agricultural and vegetable crops. On the other hand, elemental concentration in the sediment samples were found to be the following descending order of $\mathrm{Fe}>\mathrm{Mg}>\mathrm{Na}>\mathrm{K}>\mathrm{Ca}>\mathrm{Mn}>\mathrm{Zn}>\mathrm{Cr}>\mathrm{Cu}>\mathrm{Pb}>\mathrm{As}>\mathrm{Cd}$ respectively. Several pollution assessment indices: contamination factor (Cf), degree of contamination (Cd), modified degree of contamination (mCd), pollution load (PLI), enrichment factor (EF), geo-accumulation (Igeo) indices were followed to assess the sediment systems pollution in the study area. Considering sediment quality indices, this study revealed that the river sediment had higher contamination factor (Cf) values for $\mathrm{Cd}$, moderate values for $\mathrm{Pb}$, $\mathrm{Cr}, \mathrm{Cu}, \mathrm{Zn}, \mathrm{Mg}$, and As, and low values for $\mathrm{Mn}, \mathrm{Fe}, \mathrm{Ca}, \mathrm{Na}$, and $\mathrm{K}$. Among the studied heavy metals, Cd content was highest in both water and sediment samples, which confirming that Cd, insoluble or suspended form, was more likely to be strongly deposited and bound in sediments from water. Principal component and correlation analyses suggested that the sources of heavy metals pollution were mainly anthropogenic along with the geogenic sources in the study area.

\section{Introduction}

Globally, the water bodies like rivers, lakes, estuaries, bays, and oceans are the potential reservoirs for diverse contaminants including heavy metals (ILIE et al. 2017). The pollution associated with heavy metals in water bodies is one of the critical environmental concerns due to their extended toxic effects on soilwater-air-plant ecosystems and public health (Kibria et al. 2016, Mihaela llie 2017, Mohiuddin et al. 2010). Trace metals can also be delivered and absorbed into sediments of water bodies by different pathways according to their grain size and mineralogy (Haque et al. 2004), which cause long-term adverse effects to the living species. Because these metals can be persistent as well as bio-accumulative in sediments (Öğlü et al. 2015), the aquatic environment can easily be exposed to their toxicity and gets polluted simultaneously. It should be mentioned here that the sediment in aquatic ecosystems fills in a huge pool for heavy metal storage and reported that metals contaminated sediment has become a serious threat to natatory ecosystems. For instance, the authors previously documented that the heavy metal concentrations in sediment and their ecological risk due to industrial activities in Bangladesh (Rahman 2014, 2019). It should be noted that heavy metal pollution in the sediment of Sela River across the Sundarbans area is as of now thought about a high ingrained threat at the national scale (Islam 2018).

While Bangladesh is an agrarian country, the river waters are mostly using for domestic and agricultural purposes. Due to accelerated industrial activities, surface water pollution is increasing over time (Rahman 2014, Saha 2017). Therefore, the status of surface water quality in some specific regions needs to be concerned and understand by analyzing toxic metals concentration in environmental samples. Sundarbans of Bangladesh, an eco-home of incredibly rich biodiversity, is a unique ecosystem as well as one of the globally important largest contiguous mangrove wetlands of the world (Iftekhar \&lslam 2004). It consists of a complex network of water resources (around 30\% of the forest) like tidal waterways, rivers, creeks, canals, mudflats, swamps, marshes, billabongs, lakes, salt marshes, coral reefs, fens, peat bogs, etc, which originate from the freshwater streams of the feeders and distributaries of GangaBrahmaputra riverine framework and saline waters of the Bay of Bengal (Seidensticker \&Abdulhaði 1983). Due to the ecological, botanical, zoological, limnological, or hydrological performance of the forest, i.e., carbon scrubbing, protection of South Asian nation against tsunamis/cyclones, support for IUCN Red Listed-endangered species, presence of three wildlife sanctuaries, etc., it was recognized as a Ramsar Convention wetland on 1992 and World Heritage site in 1997 by UNESCO (Hails 1997). As the water resources of forests mainly maintain vibrant tidal flowing patterns through it (Iftekhar \&lslam 2004), it is obvious that the overall growth and development of an ecosystem mainly depends on its water resources. If any of the water resources in the forest is disturbed, the lives and livelihoods of residents residing in its vicinity will also be critically affected along with the whole biodiversity. Therefore, it is very important to monitor these water resources routinely for habitat conservation due to their continuous change in physical parameters, availability of food particles, and the composition of an ecosystem with time. Previous studies indicated that the water resources of Sundarbans are not out of risk from heavy metal toxicity (Ahmed et al. 2011, Haque et al. 2004, Kibria et al. 2016, Kumar \&Ramanathan 2015, Raknuzzaman et al. 2016). Sundarbans is known to be

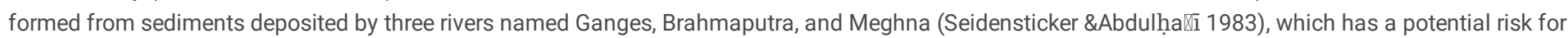
pollution and metal toxicity. Although a large part of Sundarbans is declared as Sundarbans Reserve Forests (SRF) for conserving and ensuring its wise use, the protection of SRF is entirely inadequate because the vicinity of the forest is facing unprecedented human and industrial encroachment and urbanization over years. For example, a large number of the population (around 8,55,000) living in the identified landscape near SRF, depend on the forest for their livelihood and use the resources of SRF regularly (Mission 2014). At present, about 190 different factories are installed in a $10 \mathrm{~km}$-wide belt surrounding the northeast boundary of the Sundarbans called Ecologically Critical Area (ECA) (Rahman 2005, Roy April 25, 2018). Unfortunately, these factories indiscriminately throw industrial untreated waste into the river and use several heavier water vehicles through the waterways of SRF to carry out raw materials and fuels. Moreover, the major reasons for deteriorating the quality of wild and eco-life of SRF are the use of SRF resources by nearby populations, construction of two coal-fired power plants near the forest, the release of untreated wastes of industries into the riverine aquatic environment, use of unauthorized river channel by water vehicles, oil spillage accidents (C. 2014, Ghatak 2014) into the river during transportation, etc. All these factors raise fears for the delicate water and ecology of the SRF over years.

The Sela River, an ecologically important river like the Pasur River of Sundarbans, has drawn global attention after the oil spillage accident in December 2014, when around 94,000 gallons of heavy fuel released into the river causing a lot of instant damage to the mangrove habitat and wildlife (Krishnendu Mukherjee 
\&Chakrabarty December 12, 2014, Rezwan 2014). Most importantly, the river is considered the biggest roaming sanctuary for endangered Irrawaddy Dolphins or Sushuk (WCS 2020) along with the Gangetic River Dolphin (Platanista gangeticus) and Sundarban East Wildlife Sanctuaries at the northern edge.

Therefore, it is suspected that the oil spill incident may cause a devastating threat to these endangered species and the longterm impacts on ecosystem and biodiversity have remained largely unknown. Besides, the Joymoni village residents lived on the northern edge of the SRF at the joint of Pasur and Sela Rivers (less than $3 \mathrm{~km}$ upriver) utilizes the near river water for different purposes, i.e., drinking, irrigation, harvesting fishes, farming, keeping livestock at the river's edge, etc. Consequently, the surface water quality of the Sela River may also be deteriorated by runoff of pesticides and chemical fertilizers from agricultural soils, untreated industrial effluents, municipal wastewater, etc. Recently, Ali et al. (Ali et al. 2018) and Kibria et al. (Kibria et al. 2016) reported elevated concentrations of toxic metals in water and sediments of the Pasur River. Therefore, it is also very important to monitor the level of heavy metals and the ecological character of the Sela River at a regular interval. To the best of our knowledge, this is the first attempt to ascertain the metal quality of the Sela River for human health and aquatic ecological life.

The present study aimed to monitor the concentrations of heavy metals in the water and sediment of Sela River and evaluate their environmental impact on the ecosystem as well as the lives and livelihood of the residents in the studied area. However, the specific objectives for this study: (i) to determine the major elemental concentration in surface water and sediment samples collected from Sela River, (ii) to assess heavy metal pollution (HM) using a range of HM enrichment indices ( $\mathrm{Cd}, \mathrm{mCd}, \mathrm{PLI}, \mathrm{CF}$. Igeo), (iii) to find out the level of contamination in sediment samples by reference-quality guideline, (iv) to identify the pollution sources in surface water and sediment samples in Sela River, Sundarbans, Bangladesh.

\section{Materials And Methods}

\subsection{Study area}

The Sundarbans mangrove forest covered with $30 \%$ water, is the largest mangrove wetlands of the world (WWF, 2015), which is situated in the lower Gangetic delta of South-West area ( $21^{\circ} 31^{\prime}-22^{\circ} 38^{\prime} \mathrm{N}$ and $\left.89^{\circ} 00^{\prime}-89^{\circ} 55^{\prime} \mathrm{E}\right)$ of Bangladesh. The total area of Sundarbans is $10,000 \mathrm{Km}^{2} \mathrm{covering} \mathrm{Bangladesh}$ and India, whereas $6017 \mathrm{~km}^{2}$ is encompassed in the coastal zone of Bangladesh. The area for landmass and water bodies in Sundarbans is 4143 and $1874 \mathrm{~km}^{2}$ respectively. The six major river systems, Ichamati-Raimangal, Arpangashia-Malancha, Pasur-Sibsha, Sela, and Baleswar River originating from the Ganges distributaries Mathabhanga, Bhairab, Kapotaksha, and Gorai-Madhumati, are the main reservoir of fresh water in Sundarbans. Sela River of the Sundarbans mangroves area, Bangladesh was chosen in this study (Fig. 1). It originates at the south of the Mongla port from the Pasur River on the northern side of the Chandpai range. The Mongla port area is located at $48 \mathrm{~km}$ south of Khulna city and on the confluence of the river Pasur and Mongla (presently Mongla Nulla) at Mouza Selabunia, Rampal, Bagerhat.

\subsection{Sample collection and processing}

Surface water from the pre-selected ten (10) sampling points, and sediment composite samples from the pre-selected twenty (20) geo-referenced sites were collected in and around the Sela River and its tributaries, Sundarbans, Bangladesh (Table 1). The distance between each sampling point was kept as approximately $2 \mathrm{~km}$ for water and $1 \mathrm{~km}$ for sediment (Fig. 1). The GPS reading of water and sediment sampling sites are described in Table 1.

Acid washed clean, dry screw-capped plastic samplers (Hydro Bios, Germany) were used for collecting water samples ( $2 \mathrm{~L}$ ) at 0 to $2 \mathrm{~m}$ depth, filtered to pass through $0.45 \mu \mathrm{m}$ membrane filters, acidified with ultra-pure $\mathrm{HNO}_{3}(\mathrm{pH}$ to $<2)$ and analyze. Before analysis, the water samples were stored at $4{ }^{\circ} \mathrm{C}$. In the laboratory, the digestion of water samples was performed by placing $250 \mathrm{~mL}$ of the acidified samples in a beaker and adding $2 \mathrm{~mL}$ concentrated $\mathrm{HNO}_{3}$. The samples were then evaporated, pre-concentrated to about $2 \mathrm{~mL}$ using a hot plate covering the beaker with a watch glass, and allowed to cool at room temperature. Finally, the digested samples were then filtered (using Whatman No.41 filter paper) and transferred to a $10 \mathrm{~mL}$ volumetric flask, and made up to the volume with de-ionized water. A sample blank was prepared in the same manner as sample preparation without any water sample.

About $500 \mathrm{~g}$ of sediments were collected using stainless steel Ekman grab sampler in acid-washed wide-mouth polyethylene bottles followed by air-drying at room temp. $\left(\sim 25^{\circ} \mathrm{C}\right)$ under shade for a period of 15 days, and sieved with a 2 -mm mesh. A $20 \mathrm{~g}$ sample of sediment was oven-dried at $105^{\circ} \mathrm{C}$, homogenized by a mortar and pestle to a fine powder $(<0.100 \mu \mathrm{m})$. A microwave (Microwave Accelerated Reaction System, MARS-5; CEM Corporations, USA) was operated to prepare sediment samples for the analysis of various metals following US EPA procedure $3051 \mathrm{~A}$. Approximately 0.5 of the samples were directly shifted to XP-1500 plusTM polytetrafluoroethylene digestion vessels. Duplicate, blank, spiked, and quality control samples were shifted in the vessels, and $6 \mathrm{~mL}$ of supra pure $\mathrm{HNO}_{3}$ was added to the samples. The vessels with samples were placed on the turntable motor gathering of the plate. The maximum power of the rotating magnetron was $1600 \mathrm{~W}$. The heating arrangement was as follows: (1) The temperature increases to $180^{\circ} \mathrm{C}$ with the ramping time of 15 min, (2) after levitating the temperature from 0 to $180^{\circ} \mathrm{C}$ it holds for $10 \mathrm{~min}$, and (3) cooling time of $15 \mathrm{~min}$ (time required to cool down from 180 to $60{ }^{\circ} \mathrm{C}$ or less). After digestion, the rotor assembly was moved from MARS- 5 to the fume hood where the temperature was $60^{\circ} \mathrm{C}$. After digestion and cooling, every arrangement was diluted to the last volume of $10 \mathrm{~mL}$ with deionized water (resistivity > $18 \mathrm{M} \Omega / \mathrm{cm}$, produced using an E-pure system (Thermo Scientific, USA).

\subsection{Quality control}

Individual standard solutions of target elements were purchased from Varian Inc, the USA with the highest purity level ( $99.98 \%)$. Ultra-pure $\mathrm{HNO}_{3}$ and all other chemicals were supplied by E. Merck, Germany. First, $100 \mathrm{~mL}$ of different concentrations of working standard solutions of the studied metals were prepared from stock standard solutions ( $1000 \mathrm{mg} / \mathrm{L}$ ) by diluting with Milli-Q water (water resistivity $>18.2 \mathrm{M} \Omega-\mathrm{cm}, 25^{\circ} \mathrm{C}$; Millipore, MA, USA). The Quantification of the studied metals was based on the calibration curves. Operational conditions were adjusted to yield optimal determination. The accuracy of the analytical methods was assessed by analyzing the Certified Reference Materials NIST 1640 (water matrix) and IAEA 433 (estuarine sediment). The recovery values obtained are shown as supplementary information in Tables S1(a) and S1(b). There was an acceptable agreement in the analytical data based on the 
calculation of metals recovery and precision. The recovery rate of $90 \%$ to $99 \%$ was earned and considered satisfactory for the analysis. For each sample analysis, triplicates were performed.

\subsection{Analysis of samples}

\subsubsection{Determination of physical parameters}

Several physical parameters such as temperature, dissolved oxygen, $\mathrm{pH}$, electrical conductivity, total dissolved solids were measured to identify the quality of the water samples. The temperature was determined by a digital thermometer while $\mathrm{pH}$ was measured by a pH meter (Model $\mathrm{HI} 98106, \mathrm{Portugal})$. EC and TDS were determined by a conductivity meter (CD Model 4301, England).

\subsubsection{Determination of heavy metals in water and sediment}

All the samples, i.e., standards, sample blank, water, and sediment samples were analyzed for heavy metals (except As and Hg) by Flame Atomic Absorption Spectroscopy (FAAS) while the As by Hydride Generation Atomic Absorption Spectroscopy (HGAAS) and the metal Hg by Cold Vapor Atomic Absorption Spectroscopy (CVAAS) of Varian Analytical Instruments (Models AA DUO 240 FS and AA 280 Z).

\subsection{Assessment of water and sediment quality}

To investigate the effect of the studied metals in water and sediments of Sela River, several established water and sediment quality assessment indices were computed and presented in Table 2. The water quality index (WQI), sodium adsorption ratio (SAR), sodium percentage (Na\%), pollution index (PI), metal index (MI) were used for assessing the water quality in the study area. For evaluating sediment quality, all the three types of sediment quality assessment indices (Caeiro et al. 2005) were applied: (a) contamination indices, i.e., contamination factor $\left(\mathrm{C}_{f}\right)$, degree of contamination $\left(\mathrm{C}_{\mathrm{d}}\right)$, modified degree of contamination $\left(\mathrm{mC}_{\mathrm{d}}\right)$; pollution load index (PLI); (b) background enrichment indices: enrichment factor (EF), geo-accumulation index (Igeo $)$ and ecological risk indices (Table 2).

\section{Results And Discussion}

\subsection{Physico-chemical properties of Sela river water}

The results of Physico-chemical parameters for water samples were analyzed following the standard method (APHA, 2005), which are presented in Table 3. The temperature of the Sela River water ranged from 23.0 to $24.6^{\circ} \mathrm{C}$. The average temperature $\left(24.06^{\circ} \mathrm{C}\right)$ throughout the river was assumed to be quite warm, which could enhance the growth of microorganisms and thus develop unpleasant tastes/odors if used for drinking. Prescott et al. (Prescott L.M. et al. 1999) reported the optimal temperature for the growth and survival of mesophilic bacteria including human pathogens as $\left(20-45^{\circ} \mathrm{C}\right)$. Dissolved oxygen (DO) in water plays an important role in the aerobic respiration and survival of fish communities and aquatic life lived in a water system (Wetzel 2001). For example, the concentration of DO is inversely proportional to that of the heavy metals present in the water reservoir and thus increases the toxicity of heavy metals for aquatic life. Additionally, lower DO may adversely affect the life of aquatic biota at higher water temperatures (Ojekunle et al. 2016). The criterion of DO for warm and cold water biota is $5-6$ and $6.5-9.5 \mathrm{mg} \Lambda$ respectively (WHO 2011). In this study, the DO of the studied water was found from 4.5 to $9.5 \mathrm{mg} \Lambda$ (Table 3). The average DO is $5.89 \mathrm{mg} \Lambda$ whereas the sites, W10 and W1 present the lowest and highest DO status respectively. Also, lower DO (< $5 \mathrm{mg} \Lambda$ ) was observed at sites W3, W5, W9, and W10 (4.5 $4.8 \mathrm{mg} /$ ) with temperatures $23.8,24.5,24.4$, and $24.5^{\circ} \mathrm{C}$ respectively. As the solubility of DO decreases with the increasing temperature of water (Dodds \&Whiles 2010), the studied river has a lower capacity to hold oxygen at most of the sites with warmer temperatures. On the other hand, higher concentrations of DO was also observed at some of the sites due to some physical processes like wind mixing or increased diffusion from the air (Dodds \&Whiles 2010). The diversity of a water system and the growth of bacteria in water bodies is enormously controlled by pH. Prescott et al. (Prescott L.M. et al. 1999) reported that microorganisms habitually produce acidic/basic metabolic wastes and thus the pH of the water bodies may be changed with time. The $\mathrm{pH}$ of the studied river for all water samples was slightly alkaline (7.45-8.57), which were within the permissible limit range for drinking, irrigation, and aquatic life as 6.5-8.5 (WHO 2011), 8.5 (Ayers \&Westcot 1994) and 6-9 (McPherson et al. 1999) respectively. However, the $\mathrm{pH}$ of the site, W2 was slightly higher (8.57) than the recommended value for drinking and irrigation (Table 3 ) indicating the presence of free carbon dioxide or bicarbonate in the respective sample site (Wetzel 2001).

The electrical conductivity $(\mathrm{EC})$ of a water system represents the degree to which the water body can conduct electricity. EC values mainly depend on the number of ions present in water, mobility of ions throughout the water reservoir, the valence of ions, and temperature. The range of EC values for Sela river water was from 3200 to $3800 \mu \mathrm{S} / \mathrm{cm}$, which was about 3 to 4 times higher than the recommended standard for drinking water (1000 $\mu \mathrm{S} / \mathrm{cm}$, WHO, and NAFDAC) indicating frequent microbial activities in the analyzed water (USDA-NRCS 2014).

Total dissolved solids (TDS) in water bodies are the measurement of anions, i.e., $\mathrm{CO}_{3}{ }^{2-}, \mathrm{HCO}_{3}{ }^{-} ; \mathrm{Cl}^{-}, \mathrm{SO}_{4}{ }^{2-}, \mathrm{PO}_{4}{ }^{3-}, \mathrm{NO}_{3}{ }^{-}$, and cations, i.e., $\mathrm{Ca}^{2+}, \mathrm{Mg}^{2+}, \mathrm{Na}^{+}, \mathrm{K}^{+}, \mathrm{Fe}^{2+}$ and $\mathrm{Mn}^{2+}$ present (Wetzel 2001). The TDS recorded in the studied water was $2250 \sim 2690 \mathrm{mg} /$, which was about 4 and 2 times greater than that of the recommended value for drinking water and protection of aquatic life (USDA-NRCS, 2014), respectively. As the amount of EC and TDS are related to each other, the increased EC and TDS values of the studied water suggest that the studied water samples are significantly rich in different ions, which may result from various sources, i.e., weathering of the rocks and soil minerals, sewage, agricultural run-off, wastes from the water treatment process and other industries (Ojekunle et al. 2016, Wetzel 2001).

\subsection{Quantification ofmetals in water}


Metal concentration in surface water samples was measured and presented in Table 4 along with the recommended and reference values. The ranges of concentrations in Sela River water were followed as: $\mathrm{Pb}(20 \sim 148 \mu \mathrm{g} /$ ), $\mathrm{Cd}(18.2 \sim 53.6 \mu \mathrm{g} /)$ ), $\mathrm{Cr}(23.3 \sim 53.3 \mu \mathrm{g} /)$, Co (95.6 $317.6 \mu \mathrm{g} /)$, Cu (15.3 37.5

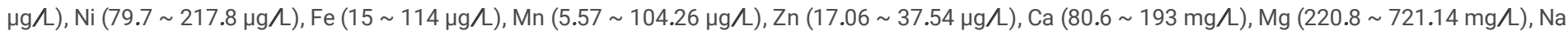
(28.78 $354.6 \mathrm{mg} /$ ) and $\mathrm{K}(83.16 \sim 223.15 \mathrm{mg} /$ ). The mean concentrations for heavy metals, i.e., $\mathrm{Pb}, \mathrm{Cd}, \mathrm{Cr}, \mathrm{Co}, \mathrm{Cu}, \mathrm{Ni}$, Fe, Mn, and $\mathrm{Zn}$ were found to be 83.71, 30.7, 34.60, 160.4, 23.6, 148.1, 73.4, 34.98, $28.01 \mu \mathrm{g} /$ respectively, whereas the concentration for light metals, i.e., Ca, Mg, $\mathrm{Na}$, and $\mathrm{K}$ was found to be $133.55,456.72,153.82$ and $148.02 \mathrm{mg} / \mathrm{L}$ respectively. Besides, the concentration of other heavy metals, As and $\mathrm{Hg}$ in river water was found to be less than the detection limits ( 3.0 and $0.3 \mu \mathrm{g} \Lambda$ for $\mathrm{As}$ and $\mathrm{Hg}$ respectively). This study revealed that the mean concentrations of heavy metals $\mathrm{Pb}, \mathrm{Cd}, \mathrm{Co}$, and $\mathrm{Ni}$, were about $8,10,20$, and 2 times higher than that of the permissible limit for potable water set by the World Health Organization (WHO 2011). Therefore, the most polluted metals in the studied river water were contaminated with the following descending order: $\mathrm{Co}>\mathrm{Cd}>\mathrm{Pb}>\mathrm{Ni}$ respectively (Table 4). It is an alarming situation because the concentrations of $\mathrm{Pb}$ and $\mathrm{Cd}$ in this study are about 3 and 15 times higher respectively than that of reported concentrations for $\mathrm{Pasur}$ River, Bangladesh (Ali et al. 2018). Also, Bhuyan et al.(2019) even noted lesser Cd and Cr concentrations, i.e., 30 and 3 times respectively, in the Brahmaputra River than the present study(Bhuyan et al. 2019)(Bhuyan et al. 2019). It might be happened due to the reason that a huge amount of Pb, Cd, Ni, $\mathrm{V}$, Zn come into surface water/environment from any oil accident (Mustafa 2015), which was happened in the study area in 2015. Furthermore, the Sela River water was a matter of warning for aquatic life due to the elevated concentrations of six heavy metals (out of 11 metals), i.e., $\mathrm{Pb}, \mathrm{Cd}, \mathrm{Co}, \mathrm{Cu}, \mathrm{Ni}$, and $\mathrm{Hg}$ (Table 4). Moreover, the heavy metals $\mathrm{Pb}, \mathrm{Cd}, \mathrm{Co}$, and $\mathrm{Ni}$ are considered to be toxic in this study. Fig. 2 shows the spatial distribution of toxic metals (Pb, $\mathrm{Cd}, \mathrm{Co}$, and $\mathrm{Ni}$ ) found in Sela River water. The most polluted sites are found to be W3, W6, W7, and W8. The major reasons for water pollution of the studied river caused by toxic metals ( $\mathrm{Pb}, \mathrm{Cd}, \mathrm{Co}$, and $\mathrm{Ni}$ ) may be anthropogenic activities, i.e., untreated industrial effluents released into the river, municipal wastes, etc in addition to the oil spelling accident.

The concentrations of light metals $\mathrm{Ca}, \mathrm{Mg}$ and $\mathrm{K}$ in surface water were about 1.77, 9, and 12 times higher than the recommended values for drinking, with a descending order of $\mathrm{K}>\mathrm{Mg}>\mathrm{Ca}$ respectively. For irrigation purposes, the concentration of metals: $\mathrm{Cd}, \mathrm{Co}, \mathrm{Mg}$, and $\mathrm{K}$ were 3.07, 3.2, 7.6, and 74 times higher than that of the recommended value (Ayers and Westcot, 1994) where the descending trend is $\mathrm{K}>\mathrm{Mg}>\mathrm{Co}>\mathrm{Cd}$ respectively. Reconstitution into insoluble secondary minerals during weathering, the transformation from rocks, and runoff fertilizers from agricultural soils may be the major source of $\mathrm{K}$ in the surface water (Mallick, 2017). The elevated concentration of Mg should not impose any health hazard except unpleasant taste and corrosion occurrence (Wetzel, 2001). Also, the concentration of Ca was too low than the required value, which could result in the deprivation of soil from essential nutrients for effective irrigation.

\subsection{Assessment of water quality indices}

\subsubsection{Water quality index (WQI)}

It is well known that the water quality index (WQI) is one of the important water pollution assessment tools for representing the overall water quality status of a water system (Brown et al. 1972). Fig. 3(a) illustrates the computed WQI values of Sela River water for different purposes, i.e., drinking (blue column), irrigation (red column), protection of aquatic life (black column). The selected parameters for portable water quality were included different Physico-chemical parameters: $\mathrm{pH}$, temperature, $\mathrm{DO}, \mathrm{EC}, \mathrm{TDS}$; major cations: $\mathrm{Ca}^{+2}, \mathrm{Mg}^{+2}, \mathrm{Na}^{+}, \mathrm{K}^{+}$and as well as a number of heavy metals: $\mathrm{Pb}, \mathrm{Cd}, \mathrm{Cr}, \mathrm{Co}, \mathrm{Cu}, \mathrm{Ni}, \mathrm{As}, \mathrm{Hg}, \mathrm{Fe}, \mathrm{Mn}$, and $\mathrm{Zn}$ respectively. While the parameters like temperature and DO were omitted for irrigation use. For aquatic life criteria, the excluded parameters were $\mathrm{Ca}{ }^{+2}$, $\mathrm{Mg}^{+2}, \mathrm{Na}^{+}, \mathrm{K}^{+}$, and Fe. The results show that the ranges of computed WQI values were $391.80 \sim 933.74,641.38 \sim 4353.91$, and $225.50 \sim 286.33$ concerning drinking water, irrigation water, and aquatic life protection respectively (Tables S2, S3, and S4). The average WQI values for drinking water, irrigation, and aquatic life were found to be 613.08, 2798.59, and 254.29 respectively (3(a)). According to the criteria of Index 1 in Table 2, higher WQI values (WQI > 100) obtained at all sample sites suggests that the water is unsuitable for any intended use. Among all purposes, the lowest water quality was found for irrigation uses, especially at sites W3, W5, W6, W8, and W9 respectively (Fig. 3(a)). This is because out of 18 parameters, TDS and K has a significant contribution to inferior water quality in the case of irrigation (Table 3, Table 4, and Tables S2, S3, S4). This study also revealed that the concentrations of Ca and Na were found to be within the recommended limit for irrigation, the water quality was further evaluated by irrigation indices, i.e., alkalinity hazard (SAR) and Na\% in the latter section (Fig. 3(b)).

\subsubsection{Alkalinity Hazard (SAR)}

SAR is known to be an assessment tool for determining the suitability of water for irrigation use by measuring the number of alkali metals like $\mathrm{Na}^{+}$, $\mathrm{Ca}^{2+}$, and $\mathrm{Mg}^{2+}$ ions (Kawo \&Karuppannan 2018, Subramani et al. 2005). The sample points of the studied river water are categorized according to SAR formula (Table 2) and shown in Fig. 3(d) and Table S5. The range of SAR at all sites was observed from 0.25 to $4.29 \mathrm{meq} / \mathrm{L}$ with an average value of 1.49 meq/L, whereas the highest and lowest SAR was found for sites W10 and W9 respectively. According to the criteria defined by SAR (Table 2, Index 4), 100\% of the studied water samples obtaining SAR < 10 were excellent water quality types for irrigation uses (Table S5). It was reported that the hydraulic conductivity of soil irrigated by water with high contents of $\mathrm{Na}, \mathrm{K}, \mathrm{Ca}$ and $\mathrm{Mg}$ showed less negative $\mathrm{K}$ effects than those for $\mathrm{Na}$ as well as less positive $\mathrm{Mg}$ effects than those for $\mathrm{Ca}$. As the deleterious effect of $\mathrm{K}$ is considered to be about one-third of that for $\mathrm{Na}$, it is necessary to contain a greater $\mathrm{Mg}$ concentration than that of $\mathrm{Ca}$ have the same beneficial effect (Smith et al. 2015). Unlike WQI, the calculated SAR values suggest that the Sela River water is suitable for irrigation usage.

\subsubsection{Percentage of sodium ( $\mathrm{Na} \%)$}

$\mathrm{Na} \%$ is also known to be an assessment tool for evaluating the suitability of water by measuring the amount of alkali metal like $\mathrm{Na}^{+}$ion present in a freshwater system if used for irrigation (Kawo \&Karuppannan 2018). The high amount of $\mathrm{Na}^{+}$ion can cause reduced soil permeability and limited circulation of air/water (Saleh et al. 1999). The percentage of (Na\%) in Sele River water for this study was calculated (Table S5) and was graphically shown in Fig. 3(b). This study revealed that $\mathrm{Na} \%$ ranging from 8.65 to 40.67 indicates the level of water quality from excellent to permissible for irrigation purposes (Table 2 , 
Index 5). The average $\mathrm{Na} \%$ (19.22) of Sela River water suggests that the study river water is categorized as excellent quality. It was observed that $60 \%, 30 \%$ (W2, W5, and W8), and 10\% (W10) of the river water samples fall into excellent, good, and permissible category respectively (Fig. 3(b) and Table S5). As the majority of the samples in the study area are of excellent quality water type, the studied river water is considered to be perfectly fit for irrigation.

\subsubsection{Metal Pollution Index (MPI)}

Another effective water pollution assessment tool for measuring the contamination status of multiple metals retained in a water system is the metal pollution index (MPI) (Department of civil engineering 1970). In this study, MPI is calculated for 11 heavy metals ( $\mathrm{Pb}, \mathrm{Cd}, \mathrm{Cr}, \mathrm{Co}, \mathrm{Cu}, \mathrm{Ni}, \mathrm{As}, \mathrm{Hg}, \mathrm{Fe}, \mathrm{Mn}$, and $\mathrm{Zn}$ ) according to the formula of Index 2 (Table 2). The results are presented in Fig. 3(c) and Table S3. The calculated MPI showed a different degree of metal pollution in the studied river water for different uses (Fig. 3(c)). The order of MPI values for drinking purposes: $\mathrm{Co}>\mathrm{Cd}>\mathrm{Pb}>\mathrm{Ca}>\mathrm{Ni}>\mathrm{Cr}>\mathrm{Mn}>\mathrm{Fe}>\mathrm{As}>\mathrm{Hg}>\mathrm{Cu}>\mathrm{Zn}$, for irrigation purpose: $\mathrm{Co}>\mathrm{Cd}>\mathrm{Ni}>\mathrm{Cr}>\mathrm{Mn}>\mathrm{Cu}>\mathrm{Hg}>\mathrm{As}>\mathrm{Pb}>\mathrm{Fe}>\mathrm{Zn}$ and for aquatic life protection: $\mathrm{Co}>\mathrm{Pb}>\mathrm{Cd}>\mathrm{Cu}>\mathrm{Ni}>\mathrm{Hg}>\mathrm{Mn}>\mathrm{Cr}>\mathrm{Zn}>\mathrm{Fe}>\mathrm{As}$ respectively. According to MPI assessment criteria (Table 2: Index 2), the metals Co (MPI:31.45), Cd (MPI: 14.56), and Pb (12.02) are assumed to be responsible for heavier pollution (MPI >10) if the water is intended to use for drinking and thus marked as toxic metals due to their adverse effects on human health (Department of civil engineering 1970). Besides, lighter pollution was noticed for Ni (MPI: 2.66). However, the metals like Cr, Cu, As, Hg, Fe, Mn, and Zn had no effect on the pollution for drinking purposes. In the case of irrigation, no heavier pollution is found for metals (Fig. 3(c) and Table S6) although moderately and lightly polluted metals are Co (MPI: 5.03) and Cd (MPI: 4.37) respectively. For the protection of aquatic life (Fig. 3(c) and Table S6), the Sela River water is considered to be heavily polluted due to the presence of toxic metals like Pb (MPI: 14.14) and Co (MPI: 31.45$)$, which may result in a serious threat to the survival of biota living in the studied river. Furthermore, the metals that exhibited lighter pollution effects on aquatic life are $\mathrm{Cd}$, $\mathrm{Cu}$, $\mathrm{Ni}$, $\mathrm{Hg}$, and $\mathrm{Mn}$. The other metals like $\mathrm{Cr}, \mathrm{As}, \mathrm{Fe}, \mathrm{Zn}$ are of good quality metals in the studied river water, which do not cause any threat to aquatic life.

\subsubsection{Metal quality index (MI)}

The metal quality index (MI) is a spatial measurement of metals found at different sites throughout the study area (Caeiro et al. 2005). MI has been calculated by Index 3 (Table 2) and the results were presented in Fig. 3(d). The mean MI values of Sela River water for drinking, irrigation, and aquatic life were found to be $42.18,7.87$, and 42.61 respectively (Table S5). As MI value $>1$ is a threshold of warning (Gülfem Bakan et al. 2010), the obtained higher MI values (> 1 ) of the river water at all sample sites indicate a "very low-quality water" for all purposes. According to another criterion for $\mathrm{MI}$ values (MI > 6.0, Index 3 , Table 2 ), all the sites through the studied river water are considered to be seriously polluted with metals. In the case of drinking, the sites W1, W3, W6, W8, and W9 are marked as highly polluted zones compared to other sites (Fig. 3d). In addition to the highly polluted zones found for drinking, the sites, W1 and W5 have also greater metal pollution for irrigation use. For the survival of aquatic biota, the sites W3, W6, W8, and W9 are also more affected sites than others. The computed MI values agreed well with that of the WQI values discussed in the previous section, where the greater pollution was also observed at sites W3, W6, W8, and W9 for different utilizations.

\subsection{Quantification of heavy metals in sediments}

Table 5 presents the concentrations of measured and earth's crust for 15 metals in Sela River sediments. The ranges of concentrations in Sela River sediments were as follows: $\mathrm{Pb}(19 \sim 31.61 \mathrm{mg} / \mathrm{kg}), \mathrm{Cd}(0.75 \sim 2.35 \mathrm{mg} / \mathrm{kg}), \mathrm{Cr}(32.11 \sim 49.45 \mathrm{mg} / \mathrm{kg}), \mathrm{Cu}(29.08 \sim 36.93 \mathrm{mg} / \mathrm{kg}), \mathrm{As}(2.23 \sim 4.09 \mathrm{mg} / \mathrm{kg}), \mathrm{Fe}$ (20240 $40481 \mathrm{mg} / \mathrm{kg}), \mathrm{Mn}(312.83 \sim 572.85 \mathrm{mg} / \mathrm{kg}), \mathrm{Zn}(63.25 \sim 84.08 \mathrm{mg} / \mathrm{kg}), \mathrm{Ca}(326 \sim 4265 \mathrm{mg} / \mathrm{kg}), \mathrm{Mg}(11646 \sim 26550 \mathrm{mg} / \mathrm{kg}), \mathrm{Na}(1485 \sim 75896$ $\mathrm{mg} / \mathrm{kg})$ and $\mathrm{K}(3913 \sim 6677 \mathrm{mg} / \mathrm{kg})$. The mean concentrations of $\mathrm{Pb}, \mathrm{Cd}, \mathrm{Cr}, \mathrm{Co}, \mathrm{Cu}, \mathrm{As}, \mathrm{Fe}, \mathrm{Mn}, \mathrm{Zn}, \mathrm{Ca}, \mathrm{Mg}$ and were 26.58, 1.37, 40.11, 33.70, 3.30, 30255, $476.64,74.4,1507.8,14311,11269$, and $4998 \mathrm{mg} / \mathrm{kg}$ respectively in the sediment samples. The metals that exceeded the reference values are $\mathrm{Pb}, \mathrm{Cd}, \mathrm{Cr}, \mathrm{Cu}$, $\mathrm{As}, \mathrm{Zn}$, and $\mathrm{Mg}$ (Table 5). It was observed that the concentrations of $\mathrm{Pb}, \mathrm{Cd}, \mathrm{Cr}$, Cu, $\mathrm{As}$, $\mathrm{Zn}$ and $\mathrm{Mg}$ were found to be 1.56, 13.43, 1.15, 2.36, 1.35, 1.43, and 1.05 times higher respectively than the reference values. Consequently, the concentration order of the elevated metals decrease as follows: $\mathrm{Cd}>\mathrm{Cu}>\mathrm{Pb}>\mathrm{Zn}>\mathrm{As}>$ $\mathrm{Cr}>\mathrm{Mg}$. Thus, it is revealed that $\mathrm{Cd}$ is the most dominant heavy metal among the quantized elevated metals in studied sediment samples.

In addition, the most polluted sites contaminated by $\mathrm{Cd}$ were the sites from 7 to 11 , where the range of $\mathrm{Cd}$ concentrations was $2.11 \sim 2.35 \mathrm{mg} / \mathrm{kg}$ indicating around 20 times greater elevation of $\mathrm{Cd}$ concentration in sediments. Other metals like $\mathrm{Fe}, \mathrm{Mn}, \mathrm{Ca}$, $\mathrm{Na}$, and $\mathrm{K}$ of the studied sediment samples was below the earth's crust value (Table 5). Besides, the least dominant metal measured in sediment samples was Ca (Table 5), which indicated that Ca is more soluble in the river water rather than present in the sediment. It is important to notice that the elevation in concentrations for Pb is lower but for Cd is higher in sediments than that of surface water due to different mineralogy and absorption capacity of metals into sediments (Haque et al. 2004).

Moreover, the elevated metals within the sampling area are supposed to be deposited from discharge effluent or municipal waste rich in those respected metals. As noticed in Table 5, the metal pollution status of the Sela River is assumed to be not only similar to the near Pasur River but also greater than the Brahmaputra River (Bhuyan et al. 2019). Therefore, it is highly expected to further investigate the pollution status of the study area by using different pollution indices (Table 2).

\subsection{Assessment of sediment quality indices}

\subsubsection{Contamination factor (Cf), Degree of contamination $\left(\mathrm{C}_{\mathrm{d}}\right)$, and Modified Degree of contamination $\left(\mathrm{mC}_{\mathrm{d}}\right)$ :}

The contamination factor $\left(\mathrm{C}_{\mathrm{f}}\right)$, the simplest and traditional approaches for evaluating the contamination status by single metals quantified from sediment analysis (Hakanson 1980). However, the $\mathrm{C}_{\mathrm{f}}$ for the studied metals in the Sela River was computed using the equation of Index 6 (Table 2 ) and depicted in Fig. 4(a). It was found that the average order of $\mathrm{C}_{\mathrm{f}}$ values for the metals was $\mathrm{Cd}(13.42)>\mathrm{Cu}(2.36)>\mathrm{As}(1.65)>\mathrm{Pb}(1.56)>\mathrm{Zn}(1.43)>\mathrm{Cr}(1.15)>\mathrm{Mg}(1.06)>\mathrm{Fe}$ $(0.98)>\mathrm{Mn}(0.90)>\mathrm{Na}(0.44)>\mathrm{K}>(0.17)$ respectively (Table S7). As noticed, the estimated average $\mathrm{C}_{\mathrm{f}}$ value of all studied sites was highest for $\mathrm{Cd}$ and lowest for $\mathrm{Ca}$ (Fig. 4(a)). According to the assessment criteria of $\mathrm{C}_{\mathrm{f}}$ (Table 2, Index 6), the Sela river has very high $\mathrm{C}_{\mathrm{f}}$ values for $\mathrm{Cd}$, moderate values for $\mathrm{Pb}$, $\mathrm{Cr}, \mathrm{Cu}, \mathrm{Zn}$, 
$\mathrm{Mg}$, As, and low values $\mathrm{Mn}, \mathrm{Fe}, \mathrm{Ca}, \mathrm{Na}, \mathrm{K}$. It is important to note that $\mathrm{Cd}$ gives $100 \%$ (S1 S20) as very high contamination due to its average $\mathrm{C}_{\mathrm{f}}>6$. The most polluted sediment contaminated by Cd (23.04) is in site S8 (Table S7). Also, the Cd profile showed an increasing trend in the middle of the sediment sites, S7 $\mathrm{S} 11$, where $\mathrm{Cd}$ may not have mobilized and thus get accumulated (Mustafa et al., 2015). Whereas for $\mathrm{Mn}, \mathrm{Fe}, \mathrm{Ca}, \mathrm{Na}$, and $\mathrm{K}$, the average $\mathrm{C}_{\mathrm{f}}<1$ was recorded suggesting low contamination in Sela River, which might be due to fewer activities triggering the accumulation of the respective metals in the sediment. However, different anthropogenic activities contribute to moderate contamination by $\mathrm{Mn}$, Fe, and $\mathrm{Na}$ at $25 \%$, $45 \%$, and $10 \%$ sample sites respectively (Table S7). On the contrary, the other metals $\mathrm{Pb}, \mathrm{Cr}, \mathrm{Cu}, \mathrm{Zn}, \mathrm{Mg}$, and As represents moderate contamination with average $\mathrm{C}_{\mathrm{f}}$ values in the range of 1 to 3 (Fig. 4(a) and Table S7). Meanwhile, $\mathrm{Pb}, \mathrm{Cu}, \mathrm{Zn}$, and As exhibited $100 \%$ as moderately contaminated. For $\mathrm{Cr}$, only $10 \%$ of sites (S9 and S11) were low contaminated over the whole profiles and the remaining stations were moderately contaminated (Table S2). The higher $\mathrm{C}_{\mathrm{f}}$ in $\mathrm{Cr}$ was found at sites, S7 and S8 regarding moderate contamination level. Besides, Mg showed nine sites (S3 S10, S20) that exhibit 45\% low contaminations whereas the remaining are accounted as moderate enrichment by anthropogenic or natural input. Therefore, the $\mathrm{C}_{\mathrm{f}}$ values of the studied heavy metals in sediments can effectively measure the contamination status for Sela River and thus indicated that the low contaminants of the Sela River sediments are Mn, Fe, Ca, Na and K whereas the moderate contaminants are $\mathrm{Pb}, \mathrm{Cr}, \mathrm{Cu}, \mathrm{Zn}, \mathrm{Mg}$ and $\mathrm{As}$ and the very high contaminant is $\mathrm{Cd}$.

Fig. 4(b) and Table S7 depicted the degree of contamination $\left(C_{d}\right)$ of all the studied sediments for Sela River by summing the above-depicted $C_{f}$ values (Table 2, Index 7). The estimated $C_{d}$ values ranged from 19.51 to 37.55 and according to the classification of Index 7 (Table 2), the $C_{d}$ values indicated from considerable (S1 S6, S12, S17 S20) to a very high (S7 S11) degree of contamination in the Sela River sediments. The maximum degree of contamination was found for site $S 11\left(C_{d}: 37.55\right)$. The average $C_{d}$ value of all sites is 25.18 , which is above 24 denoting a very high degree of contamination of Sela river sediments. Additionally, the $\mathrm{C}_{f}$ and $\mathrm{C}_{\mathrm{d}}$ values (Table S7) demonstrated that the higher accumulation of Cadmium (Cd) metal in the sediments may contribute to the most contaminated sites (S7 $\sim$ S11, S13 S16) in the studied area.

To figure out the effect of the number of contaminants on the pollution status of the studied area, the modified degree of contamination ( $\mathrm{mC}_{\mathrm{d}}$ ) (Abrahim \&Parker 2002) was calculated and presented in Fig. 4(c) and Table S4. As $\mathrm{mC}_{\mathrm{d}}$ is the modified version of $\mathrm{C}_{\mathrm{d}}$, all sediment sites finally indicate a moderate to low degree of sediment contamination (Table 2, Index 8: $2.0 \sim<4$ ). However, the contamination pattern of all sites obtained from the mC $\mathrm{C}_{\mathrm{d}}$ profile agreed well with that of the $\mathrm{C}_{\mathrm{d}}$. For example, like $\mathrm{C}_{\mathrm{d}}$ values, the five most deteriorated sediment sites in the Sela river were also observed to be S7 S11 and S13 S16 having the highest $\mathrm{mC}_{\mathrm{d}}$ values, well above the threshold for a moderate degree of contamination $(2 \sim<)$.

\subsubsection{Pollution Load Index (PLI)}

Fig. 4(d) shows the distribution of PLI values for all sample sites in the Sela River. As observed in Fig. 4(d), the PLI values varying from 1.34-16.57 (Table S7) were significantly higher than 1 for $100 \%$ of the sites demonstrating metal pollution of all sites to some extent according to the classification of PLI (Table 2 , Index 9). The sample sites, S11 S16 and S18 were marked as the most polluted sites having PLI values ranged from 14.63 16.57. On the other hand, the less but not the least polluted sites were S4, S5, and S9 having PLI values of 1.59, 1.46, and 1.34 respectively. Comparatively, higher sediment pollution was found for the rest of the sites. The higher PLI values of Sela River sediments might be originated from different anthropogenic inputs, i.e., non-treatment industrial waste discharge, agricultural runoff, etc. polluted by the studied heavy metals. Besides, the contribution of individual metals to the PLI values can be evaluated from the $C_{f}$ values. As notified from Fig. $4(a)$, the $C_{f}$ of $C d$ went beyond the maximum limit $\left(C_{f}>6\right)$ denoting very high concentration, whereas the $C_{f}$ of $\mathrm{Pb}, \mathrm{Cr}, \mathrm{Cu}, \mathrm{Zn}, \mathrm{Mg}$, and $\mathrm{As}$ was in the range of moderate contamination. Consequently, the metal Cd was mainly responsible for major pollution, and the other metals like $\mathrm{Pb}, \mathrm{Cr}, \mathrm{Cu}, \mathrm{Zn}, \mathrm{Mg}$, As may cause moderate pollution in the Sela river sediments. On the contrary, the $\mathrm{C}_{\mathrm{f}} \mathrm{values}$ of $\mathrm{Mn}$, $\mathrm{Fe}$, $\mathrm{Ca}$, $\mathrm{Na}$, and $\mathrm{K}$ are low $(<1)$ for most of the sample sites specifying them as non-pollutants in Sela river sediments. Thus, the increased rate of non-treated industrial waste discharged into the Sela river may cause probable environmental pollution of the river sediments especially with dangerous heavy metals like $\mathrm{Cd}$, $\mathrm{Pb}$, $\mathrm{Cr}$, $\mathrm{Cu}$, $\mathrm{Zn}$, and As. It was reported that Pasur River's sediments also faced metal contamination (Table 5) due to the elevated concentrations of heavy metals like Pb, $\mathrm{Cd}, \mathrm{Cr}$, As (Ali et al. 2018). It is important to note that the difference in indices may result due to the difference in sensitivity of these indices towards the sediment pollutants (Kayode O. Adebowale et al. 2009, M. S. Praveena et al. 2007).

\subsubsection{Enrichment factors (EF)}

The computation of EF was performed by geochemical normalization of the measured concentrations of heavy metal to a "conservative" element like Fe (Rule 1986) for reducing metal variability due to the similar geochemistry of Fe to that of many trace metals and uniform natural concentration (Daskalakis \&O'Connor 1995). To further evaluate the anomalous metal contributions in sediments of the studied river, the enrichment factors (EF) of studied metals were computed and the results are shown in Fig. 5(a).

According to the classification of EF in Table 2, most of the metals are significantly enriched in the studied sediments except for Ca and $\mathrm{K}$ (Fig. 5(a)). The EF values for $\mathrm{Pb}$ range from 1.23 to 2.3, Cd from 5.99 to 29.98 , Cr from 0.93 to 1.76, Mn from 0.58 to 1.31, Cu from 1.88 to 3.76 , Zn from 1.21 to 2.08, Ca from 0.01 to $0.18, \mathrm{Mg}$ from 0.85 to 2.14 , Na from 0.06 to $3.2, \mathrm{~K}$ from 0.15 to 0.21 , As from 1.2 to 2.29 (Table S8). Overall, the order of average EF values for the metals is $\mathrm{Cd}(14.18)>\mathrm{Cu}(2.46)>\mathrm{As}(1.71)>\mathrm{Pb}(1.61)>\mathrm{Zn}(1.48)>\mathrm{Cr}(1.19)>\mathrm{Mg}(1.10)>\mathrm{Mn}(0.94)>\mathrm{Na}(0.44)>\mathrm{K}(0.18)>\mathrm{Ca}(0.06)(\mathrm{Table} \mathrm{S} 8)$. The concentration ranges of metals $\mathrm{Ca}$ and $\mathrm{K}$ exhibited $\mathrm{EF}<1$ (Table 2, Index 10) suggesting their abundance in sediments from mainly crustal materials or natural weathering processes and as a result no significant contribution from non-crustal sources. Although the EFs (average) of $\mathrm{Na}$ and $\mathrm{Mn}<1.0$, those metals still showed enrichments at some sites from non-crustal sources. For example, minor and moderate Na enrichments were at sites S12 (1.09) and S11 (3.2) respectively whereas minor Mn enrichments were at sites S3 (1.06), S5 (1.31), S7 (1.00), S8 (1.27), S17 (1.00) and S20 (1.00).

Among the anthropogenic-contributing metals, $\mathrm{Pb}, \mathrm{Cr}, \mathrm{Mn}, \mathrm{Cu}, \mathrm{Zn}, \mathrm{Mg}, \mathrm{Na}$, and As showed evidence of minor modification ( $\mathrm{EF}, 1.0 \sim<3)$ in their enrichments although Cu was moderately enriched at only two sites, S5 (3.76) and S8 (3.23). The only severely enriched metal (EF, $10 \sim<25)$ in sediments was found to be 
Cd (average EF, 14.18), which yield vibrant enrichments (moderately to very severe) along the studied area as shown in Fig. 5(a). As observed, most of the sites suffered from severe Cd enrichment except the sites S12, S14, S17 S20 having moderate Cd modification. It is a matter of great concern that the most enriched site in Cd was S8 (EF, 29.98), which was marked for very severe enrichment (EF, $25 \sim<50)$. Consequently, Cd is assumed to be the most toxic sediment-bound metal in this study. In addition, it was noticed from Fig. 5(a) that the sites S8 S11 are comparatively more polluted than the other sites as they are located at the inner part of the Sela River. It is well known that the geological formations and soil leaching could be partially responsible for the occurrence of heavy metals in sediments, mainly at the inner part of the river (Ohta et al. 2007, Simeonov et al. 2003). As the metals showing enrichment (EF $>1.0$ ) are considered to be indicative of human influences, the enrichment of sediments with toxic elements (Cu, Cd) may also be due to the streams, uncontrolled wastewater discharges, and long transportation phenomena (Nolting et al. 1999). The major cause for observation of a high amount of Cd might be due to the deposition of toxic metals from the oil spill that occurred at Sela River on $9^{\text {th }}$ December 2014 (BBC 2014, Krishnendu Mukherjee \&Chakrabarty. 2014). The other minor contributions might be various anthropogenic intrusions in the coastal region of Bangladesh, i.e., automobile industries, ship breaking activities (Raknuzzaman et al. 2016).

\subsubsection{Geoaccumulation index (lgeo}

The environmental assessment based geoaccumulation index ( $\left.\mathrm{I}_{\text {geo }}\right)$ of Muller's expression (Table 2, Index 11) for the studied area was calculated (Table S9) and was graphically shown in Fig. 5(b). The estimated $\mathrm{I}_{\text {geo }}$ values for the metals of environmental interest are $(-0.20 \sim 0.02)$ for $\mathrm{Pb},(0.69 \sim 1.19)$ for $\mathrm{Cd}$, (-0.21 $\sim-0.03)$ for $\mathrm{Cr}$, (-0.40 -0.14) for Mn, (0.13 0.24) for $\mathrm{Cu},(-0.36 \sim-0.0)$ for $\mathrm{Fe},(-0.09 \sim 0.03)$ for Zn, $(-2.13 \sim-1.03)$ for $\mathrm{Ca},(-0.24 \sim 0.12)$ for $\mathrm{Mg},(-1.41 \sim 0.29)$ for $\mathrm{Na},(-1.04 \sim-0.10)$ for $\mathrm{K}$ and $(-0.13 \sim 0.73)$ for As. The average Igeo values tabulated in Table $\mathrm{S} 9$ are $\mathrm{Pb}(-0.06), \mathrm{Cd}(0.92), \mathrm{Cr}(-0.12), \mathrm{Mn}(-0.23), \mathrm{Cu}(0.20)$, $\mathrm{Fe}(-0.19), \mathrm{Zn}(-0.02), \mathrm{Ca}(-1.57), \mathrm{Mg}(-0.16), \mathrm{Na}(-0.85), \mathrm{K}(-0.94), \mathrm{As}(0.04)$. As noticed, the pollution intensity order of average $\mathrm{I}_{\text {geo }} \mathrm{values}$ for the metals is as follows: $\mathrm{Cd}(0.92)>\mathrm{Cu}(0.2)>\mathrm{As}(0.04)>\mathrm{Zn}(-0.02)>\mathrm{Pb}(-0.06)>\mathrm{Cr}(-0.12)>\mathrm{Mg}(-0.16)>\mathrm{Fe}(-0.19)>\mathrm{Mn}(-0.23)>\mathrm{Na}(-0.85)>\mathrm{K}(-0.94)>\mathrm{Ca}(-1.57)$. Among the analyzed parameters of sediments in the studied river, only three metals $\mathrm{Cd}$, Cu and As having average $\mathrm{I}_{\text {geo }}>0$ were classified as uncontaminated to moderately contaminated metals. Whereas, the other metals, i.e., $\mathrm{Pb}, \mathrm{Cr}, \mathrm{Mg}, \mathrm{Fe}, \mathrm{Mn}, \mathrm{Na}, \mathrm{K}, \mathrm{Ca}$ were below the practically uncontaminated status (average $\mathrm{I}_{\text {geo }}<$ 0 ) suggesting that the area is not significantly polluted by these metals. Depending on each metal and sample sites, some deviations in $I_{\text {geo }}$ values were also observed. For example, $25 \%$ of the sample sites (S7 S11, I Ieo: 0.71 to 1.19) reflects a 'moderately Cd-contamination' level (I geo: $1 \sim 2$ ). Additionally, $25 \%$ of the sites (S2 S4, S9, and S19) were considered to be practically uncontaminated $\left(\mathrm{I}_{\text {geo }}<0\right)$ by As. Besides, the $\mathrm{I}_{\text {geo }}$ value $>0$ was observed at some sample sites in case of metals having negative average $\mathrm{I}_{\text {geo }}$ values, i.e., $\mathrm{Pb}(\mathrm{S} 7=0.005, \mathrm{~S} 8=0, \mathrm{~S} 10=0.001, \mathrm{~S} 11=0.02, \mathrm{~S} 13=0.02, \mathrm{~S} 15=0.0003)$; Zn $(\mathrm{S} 13=0.03, \mathrm{~S} 14$ $=0.03, \mathrm{~S} 15=0.02, \mathrm{~S} 17=0.003, \mathrm{~S} 19=0.001, \mathrm{~S} 20=0.02) ; \mathrm{Mg}(\mathrm{S} 11=0.12)$ and $\mathrm{Na}(\mathrm{S} 11=0.29)$. Therefore, it was assumed from these deviated $\mathrm{I}_{\text {geo }}$ values that the studied metals of Sela river sediments may be possibly prone to more gradual contamination if proper measures are not taken into consideration in the future.

\subsubsection{Sediment quality guideline (SQG)}

Sediment quality guideline value (SQGV) is the criteria of tolerable concentrations of analyzed metals in sediments, which eventually predict the toxicity for protecting the aquatic biota living in that area (Burton 2002, McCready et al. 2006). The two commonly used SQG approaches reported are effective range low/median (ERL/ERM) trigger values and threshold/probable effect level (TEL/PEL) (Burton 2002). The recommended SQGVs (ERL/TEL) represents the threshold value below, which infrequent adverse effects would be found upon living biota in or near sediments. On the other hand, the upper SQGV (ERM/PEL) represents the high probability of effect on living organisms of the studied area (Burton 2002).

In this study, the distribution of analyzed eight metals ( $\mathrm{Pb}, \mathrm{Cd}, \mathrm{Cr}, \mathrm{Mn}, \mathrm{Cu}, \mathrm{Fe}, \mathrm{Zn}$, and $\mathrm{As}$ ) bound to sediments throughout the study area was achieved according to SQGV (Table 6) and shown in Fig. 6(a) and 6(b). As noticed, metals like Pb, Zn, and As were distributed in 100\% of the sediment samples that did not exceed the ERL/TEL values indicating rare toxic effects to the river biota. However, the concentration of $\mathrm{Cr}$ was $<$ ERL for $100 \%$ samples but $<$ TEL for $15 \%$ samples. In addition, 45 and $50 \%$ of sediment samples had $\mathrm{Cd}$ and $\mathrm{Cu}$ concentrations respectively, in the range of ERL $\sim$ ERM indicating occasional adverse effects to the river biota. Furthermore, the concentrations of metals $\mathrm{Cd}, \mathrm{Cr}, \mathrm{Mn}, \mathrm{Cu}$, and Fe falling in the range of TEL PEL were observed for $100 \%, 85 \%$, $70 \%$, $15 \%$, and $95 \%$ samples respectively, where occasional adverse biological effects are predicted. At last, but not least only $5 \%$ of samples had Fe distribution less than PEL. However, it is well known that the concentration of Iron (Fe) may not be considered as a serious threat to the aquatic organism and human beings' health (Burton 2002). Moreover, the concentration of metals like $\mathrm{Cd}, \mathrm{Cr}, \mathrm{Mn}, \mathrm{Cu}$, and Fe measured at different sites is a matter of future concern as the distribution of these metals is already in the middle range (ERL-ERM/TEL-PEL) of toxicity toward living organisms. If proper steps are not taken in time, the concentrations of these heavy metals may exceed the limit of ERM/PEL, which would present a significant risk to the lifestyle of biota lived near the metalbound sediments.

For evaluating the combined toxicity level of different metals retained in sediments and identifying the affected sediment sites, the more realistic and effective SQG measurement, which is mean SQG quotients, i.e., Effective range median mean quotient (ERMQ), Probable effect level mean quotient (PELQ) were also used in this study (Table 2 Index:12] (Chapman \&Mann 1999). The results are presented in Fig. 6(c) and Table S10. According to Table 2 (Index 12 ), all the sediment sites of the Sela River showed medium-low toxicity (ERMQ: $0.11 \sim 0.5$; PELQ: $0.11 \sim 1.5$ ) to aquatic biota as the average ERMQ and PELQ is 0.12 ( $30 \%$ toxicity) and 0.36 (25\% toxicity) respectively. Therefore, the computed medium-low toxic SQG quotients suggested that it is a proper time for routine monitoring of heavy metals pollution nearby Sela River and assuring the survival of aquatic ecology in the future so that the living organisms of that area could be safe from further exposure of toxic metals.

\subsubsection{Environmental Toxicity Quotient}

Environmental Toxicity Quotient, another important ecological risk index for assessing sediment toxicity, was calculated in this study and presented in Fig. 6(d) and Table S10. According to the ETQ based toxicity level (Table 2, Index 13), the average ETQ value (268.68) confirmed that the sediments of the Sela 
River are very highly toxic to the aquatic biota. It is important to note that extremely high toxicity would be observed at the sites S12 S14, S17, and S20. Besides, the sediment sites, S2, and S12 had the lowest and highest toxicity respectively (Table S10). It should be mentioned that the sites S12 S14 were also found to be highly contaminated in PLI computation in previous sections (Fig. 4(d)).

\subsection{Source identification}

\subsubsection{Principal component analysis (PCA)}

Principal component analysis (PCA) was performed on the river water and sediment quality data using Varimax rotation with Kaiser Normalization, which was used in this study to elucidate the observed relationship of cluster variables in simple ways (Mertler 2005). The calculated factor loadings, together with cumulative percentage, and percentages of variance explained by each factor are shown in Table 7. Table 7 shows that three factors were extracted for both water and sediment quality data sets based on eigenvalues more than 1 (Fig S1), which represented $87.42 \%$ and $81.25 \%$ of the total variance in the study area. For water quality data, it was observed that PC1 in the data sets explained $57.62 \%$ of the total variance, and it was positively loaded with $\mathrm{Cr}$, Co, $\mathrm{Ni}$, $\mathrm{Fe}$, $\mathrm{Zn}$ (anthropogenic sources) in association with Mg and K (geogenic sources) in Sela River water (Bodrud-Doza et al., 2016). It might be happened due to the reasons that these potential heavy metals ( $\mathrm{Cr}, \mathrm{Co}, \mathrm{Ni}, \mathrm{Fe}$, and $\mathrm{Zn}$ ) can be assimilated in river water through metal activities/industrial effluents (Saha 2017). Several industries such as ceramics, brick, pottery, petroleum refinery, shipbreaking industries are located in the study area, which is responsible for these heavy metals' presence in Sela River water (Rahman 2019). PC2 represented $17.86 \%$ of the variance and loaded heavily on Pb and Cd, which also indicating the anthropogenic sources of pollution by $\mathrm{Pb}$ and $\mathrm{Cd}$ (Rahman 2014), as well as hundreds of boats and small ships, are running on the river every day. PC3 explained $11.95 \%$ of the variance, showed high (>0.95) positive loading (Table 7(a)) on Cu and Mn, that is indicating the sources of pollution by Cu and Mn is anthropogenic in the Sela River. Therefore, these three components play a critical role in explaining metal contamination in the surface water of the Sela River, and subsequently, the graphic representation of the three components is shown in Fig. 7(a).

On the other hand, the sediment quality data revealed that three principal components have been taken into consideration and accounted for the total variation of data in order with a cumulative variance of $81.26 \%$ in Sela River (Table 7(b)). It was observed that PC1 was accounted for $44.99 \%$ of the total variance and had high $\mathrm{Cr}, \mathrm{Mn}, \mathrm{Cu}$, and $\mathrm{Zn}$ in association with the crustal metals ( $\mathrm{K}, \mathrm{Fe}$, and $\mathrm{As}$ ), which indicates that anthropogenic toxic metals ( $\mathrm{Cr}$, $\mathrm{Mn}$, $\mathrm{Cu}$, and $\mathrm{Zn}$ ) coming into sediment and trapped with the crustal metals. This PCA data is consistent with the reported result in the literature mentioning that about $43.34 \%$ of the total variance explained by the first factor (PC1) is correlated with $\mathrm{Ni}, \mathrm{Cr}, \mathrm{Pb}$, and $\mathrm{Co}$, which represents the anthropogenic sources originated from domestic/municipal wastewaters and vehicle emissions (Ustaoğlua 2020). PC2 is strongly loaded with Na and Mg and accounted for $23.98 \%$ of the total variance, which indicates that abundant of $\mathrm{Na}$ and $\mathrm{Mg}$ might be lithologic sources (Dietrich 2020). Subsequently, PC3 accounted for $12.33 \%$ of the total variance and highly loaded with $\mathrm{Cd}(>0.95)$ and moderately loaded with $\mathrm{Pb}(<0.69)$, which suggested that the sediment of Sela River was loaded with $\mathrm{Pb}$ and Cd for anthropogenic activities (Wang 2020) in the study area. However, the relationship between the contaminants based on the first three principal components is illustrated in Fig. 7(b). It can be seen from this Figure that the sediment data associated with different metal sources are indeed separated, so categorization into different pollution sources is meaningful.

\subsubsection{Correlation matrix analysis}

The relationships between variables for both water and sediment quality data were analyzed by the Pearson correlation matrix, and the results are presented in Table 8. It should be mentioned here that the high degree of correlation between element concentrations suggested either a common or a similar geochemical behavior origin (Mertler 2005). From Table 8, it could be observed that there was a strong correlation of Cd with Ni $(r=0.877), \mathrm{Zn}(r=0.731), \mathrm{Ca}(r=0.696), \mathrm{Mg}$ $(r=0.686)$ and $\mathrm{K}(r=0.699)$ in water sample, which indicating the sources of metals are anthropogenic and geogenic (Edet 2002). Subsequently, Cr showed the same type of positive correlation with $\mathrm{Ni}, \mathrm{Zn}, \mathrm{Fe}, \mathrm{Ca}, \mathrm{Mg}$, and $\mathrm{K}$ (Table 8(a)), which was consistent with the principal component analysis (Table 7). On the other hand, Zn showed positive and strong correlation with Cd ( $r=0.731), \mathrm{Cr}(r=0.784), \mathrm{Ni}(r=0.849)$, and Fe (r=0.895). It may be attributed to anthropogenic sources of metals in surface water (Saha 2017) of the Sela River, which was also observed in PC analysis (Fig. 7(a)). The correlation among the other elements in surface water samples could be found in Table 7(a). However, sediment-water quality data also used to explore the relationship between the elements and presented in Table 7(b). This study revealed that geogenic element: $\mathrm{K}$ was positively correlated with $\mathrm{Pb}, \mathrm{Mn}, \mathrm{Cu}, \mathrm{Fe}, \mathrm{Zn}$ and $\mathrm{As}$; suggesting that the anthropogenic sources originated from domestic/municipal/industrial effluents that come into surface water and eventually trapped into the river sediment in the study area. On the other hand, strong positive correlation was observed between $\mathrm{Pb}$ (main emission source of industries + vehicles) and $\mathrm{Cd}(r$ $=0.501), \mathrm{Cu}(r=0.469), \mathrm{Fe}(r=0.491), \mathrm{Zn}(r=0.675)$ and As $(r=0.613)$. It should be mentioned here that this analysis revealed a significant positive relationship for each metal at $99 \%$ and $95 \%$ confidence level, which indicated that a significant relationship exists between water bodies and surface sediment in aquatic systems of the Sela River. Therefore, the elemental association may signify that each paired elements have an identical or common source in the aquatic systems (Singh 2002).

\section{Conclusion}

This study confirmed that the heavy metal concentrations in the surface water and sediments of Sela River, Sundarbans, Bangladesh are remarkably high, for which the river is facing probable environmental pollution especially with dangerous heavy metals (Co, $\mathrm{Cd}, \mathrm{Cu}, \mathrm{Pb}, \mathrm{Cr}, \mathrm{As}, \mathrm{Ni}$ and $\mathrm{Zn}$ ). To elucidate the pollution status, several diverse and useful indices have been employed on water and sediment samples of Sela River, Sundarbans, Bangladesh. The metal pollution index (MPI) of water reveals that the surface water is highly polluted with metal toxicity as $\mathrm{Co}>\mathrm{Cd}>\mathrm{Pb}>\mathrm{Ni}$ respectively. Several water quality indices were used to assess the water quality for the application of drinking and agricultural purposes using Physico-chemical properties and metal concentration found in water samples. Considering the water quality index (WQI), metal pollution index (MPI), and metal quality index (MQI) values, this study suggested that surface water in the Sela River was not suitable for drinking purposes. Reversely surface water in the Sela River was found to be suitable for agricultural purposes considering several water quality indices. For instance, alkalinity hazard (SAR) values showed that $100 \%$ of the studied water samples obtaining SAR $<10$, 
which indicating excellent water quality types for irrigation uses in the study area. Subsequently, sodium percentage (Na\%) revealed that $60 \%, 30 \%$, and $10 \%$ (W10) of the river water samples fall into excellent, good, and permissible category respectively suggesting the majority of the samples in the study area are excellent quality water type. In addition to SAR and $\mathrm{Na} \%$ data, metal pollution index (MPI) and metal quality index (MI) revealed that there no significant pollution was found for agricultural purposes.

On the other hand, several sediment quality indices: contamination factor $\left(\mathrm{C}_{\mathrm{f}}\right)$, degree of contamination $\left(\mathrm{C}_{\mathrm{d}}\right)$ and modified degree of contamination $\left(\mathrm{mC}_{\mathrm{d}}\right)$, pollution load (PLI), enrichment factor (EF), geo-accumulation ( $\left.I_{\text {geo }}\right)$ were applied to assess the sediment quality in the study area. The EF and $I_{\text {geo }}$ of most of the heavy metals indicate that the sediments are severely enriched in Cd and cause moderate contamination of the studied river. The PLI derived from $\mathrm{C}_{\mathrm{f}}$ shows that the most polluted water sites were found to be randomly distributed (i.e., W1, W3, W6, W8, and W9) for all-purpose uses whereas the toxic metals are mostly accumulated in the middle part of sediments of the study area (i.e., S7 S16).

However, Pollution source identification through principal component (PC) analysis and correlation analysis data revealed that three factors were major sources of pollution for both groundwater and sediment samples in Sela River, representing $87.42 \%$ and $81.25 \%$ of the total variance. This study revealed that pollution sources by several heavy metals (i.e., $\mathrm{Cr}, \mathrm{Cu}, \mathrm{Mn}, \mathrm{Co}, \mathrm{Ni}, \mathrm{Fe}, \mathrm{Zn}$ in the study area) were mainly anthropogenic and some metals ( $\mathrm{Na}$, $\mathrm{K}$, $\mathrm{Mg}$, $\mathrm{Ca}$ ) are partially geogenic (natural). On the other hand, the Pearson correlation analysis among 13 elements revealed that metals coming from anthropogenic sources were correlated with metals of geogenic sources, which suggests that sources of pollution in the study area were both anthropogenic and natural. The findings results would beneficiate to take effective measures for sustaining and conserving the Sela River. The present study can also be recorded for future monitoring of the water and sediment quality of the Sela River, which would be helpful to halt environmental pollution and adverse effects on the diverse ecosystem of Sundarbans, Bangladesh.

\section{Declarations}

\section{Acknowledgments}

The authors are grateful to the authority of the Bangladesh Atomic Energy Commission (BAEC) for providing help during field sampling and sample analyses. The authors also acknowledge International Atomic Energy Agency for providing support through the project "IAEA RAS7028". The authors are also thankful to Md. Shahidur Rahman Khan, Analytical Chemistry Laboratory, Chemistry Division, Atomic Energy Centre, Dhaka for helping laboratory works.

\section{Conflict of Interest}

The authors declare no competing financial interest.

\section{CRediT authorship contribution statement}

Tasrina Rabia Choudhury: Conceptualization, Data curation, Instrumental analysis, Funding acquisition, Project administration, Software, Supervision, Methodology, Validation, Investigation, writing - review \& editing. Thamina Acter: Preparation the initial draft, Nizam Uddin: Preparation the initial draft, Masud Kamal: Funding acquisition \& project administration, A.M. Sarwaruddin Chowdhury: Reviewing, Rafiq Islam Khandekar: review \& editing, M. Safiur Rahman: Review and editing.

Ethical Appoval: Not Applicable

Consent to participate: Not Applicable

Consent to Publish: Not Applicable

Availability of data and materials: All data generated or analysed during this study are included in this published article [and its supplementary information files]

\section{References}

1. Abrahim G, Parker R (2002): Heavy-metal contaminants in Tamaki Estuary: impact of city development and growth, Auckland, New Zealand. Environmental Geology 42, 883-890

2. Abrahim GMS, Parker RJ (2008): Assessment of heavy metal enrichment factors and the degree of contamination in marine sediments from Tamaki Estuary, Auckland, New Zealand. Environmental Monitoring and Assessment 136, 227-238

3. Ahmed K, Mehedi Y, Haque R, Mondol P (2011): Heavy metal concentrations in some macrobenthic fauna of the Sundarbans mangrove forest, south west coast of Bangladesh. Environmental Monitoring and Assessment 177, 505-514

4. Ali A-e, Strezov V, Davies PJ, Wright I (2018a): River sediment quality assessment using sediment quality indices for the Sydney basin, Australia affected by coal and coal seam gas mining. Sci. Total Environ. 616-617, 695-702

5. Ali MM, Ali ML, Islam MS, Rahman MZ (2018b): Assessment of toxic metals in water and sediment of Pasur River in Bangladesh. Water Science and Technology 77, 1418-1430

6. Angulo E (1996): The Tomlinson Pollution Load Index applied to heavy metal, 'Mussel-Watch' data: a useful index to assess coastal pollution. Sci. Total Environ. 187, 19-56

7. Anonymous (2015): The Priority List of Hazardous Substances, US Agency for Toxic Substances and Disease Registry (ATSDR) 
8. ANZECC (2000): Australian and New Zealand guidelines for fresh and marine water quality. Australian and New Zealand Environment and Conservation Council, Agriculture and Resource Management Council of Australia and New Zealand

9. Ayers RS, Westcot DW (1994): Water quality for agriculture. Food and Agriculture Organization (FAO) of the United Nations, Rome 29, M-56

10. BBC (2014): India on alert after Sunderbans oil spill in Bangladesh, BBC News

11. Bhuyan MS, Bakar MA, Rashed-Un-Nabi M, Senapathi V, Chung SY, Islam MS (2019): Monitoring and assessment of heavy metal contamination in surface water and sediment of the Old Brahmaputra River, Bangladesh. Applied Water Science 9, 125

12. Boyd CE (2000): Water Quality: An Introduction. Springer US

13. Brown RM, McClelland NI, Deininger RA, O'Connor MF (1972): A Water Quality Index - Crashing the Psychological Barrier. In: Thomas WA (Hrsg.), Indicators of Environmental Quality. Springer US, Boston, MA, pp. 173-182

14. Burton JGA (2002): Sediment quality criteria in use around the world. Limnology 3, 65-76

15. A (2014): After oil spill in Bangladesh's unique mangrove forest, fears about rare animals. National Geographic

16. Caeiro S, Costa MH, Ramos TB, Fernandes F, Silveira N, Coimbra A, Medeiros G, Painho M (2005): Assessing heavy metal contamination in Sado Estuary sediment: An index analysis approach. Ecol. Indic. 5, 151-169

17. CCME (1999): Canadian environmental quality guidelines Canadian Council of Ministers of the Environment

18. Chapman PM, Mann GS (1999): Sediment Quality Values (SQVs) and Ecological Risk Assessment (ERA). Mar. Pollut. Bull. 38, 339-344

19. Daskalakis KD, O'Connor TP (1995): Normalization and Elemental Sediment Contamination in the Coastal United States. Environ. Sci. Technol. 29, 470477

20. Department of civil engineering SU, Syracuse, New York 13210 (1970): Benefits of water quality enhancement, Environmental Protection Agency (EPA), pp. 1-201

21. Dietrich M, Best, K.B., Raff, J.L., Ronay, E.R. (2020): A first-order geochemical budget for suspended sediment discharge to the Bay of Bengal from the Ganges-Brahmaputra river system. Sci. Total Environ. 726, 138667

22. Dodds WK, Whiles MR (2010): Freshwater ecology: concepts and environmental applications of limnology (2nd edition). Academic PressBurlington, MA,

23. Edet AE, Offiong, O.E., (2002): Evaluation of water quality pollution indices for heavy metal contamination monitoring. A study case from AkpabuyoOdukpani area, Lower Cross River Basin (southeastern Nigeria). Geo Journal 5, 295-304

24. Ergin M, Saydam C, Baştürk Ö, Erdem E, Yörük R (1991): Heavy metal concentrations in surface sediments from the two coastal inlets (Golden Horn Estuary and İzmit Bay) of the northeastern Sea of Marmara. Chemical Geology 91, 269-285

25. Ghatak A (2014): Oil spill on a Sundarbans river triggers environment concerns, bdnews24.com

26. Gülfem Bakan, Hülya Böke Özkoç, Sevtap Tülek, Cüce H (2010): Integrated Environmental Quality Assessment of Kizilirmak River and its Coastal Environment. Turkish Journal of Fisheries and Aquatic Sciences 10, 453-462

27. Hails AJ (1997): Wetlands, Biodiversity and the Ramsar Convention. Ramsar Convention Bureau, Ministry of Environment and Forest, India

28. Hakanson L (1980): An ecological risk index for aquatic pollution control.a sedimentological approach. Water Research 14, 975-1001

29. Hans Wedepohl K (1995): The composition of the continental crust. Geochimica et Cosmochimica Acta 59, 1217-1232

30. Haque R, Ahmad JU, Chowdhury MDA, Ahmed K, Rahman MS (2004): Seasonal variation of heavy metals concentration in surface water of the rivers and estuaries of sundarban mangrove forest. Asian Journal of Microbiology, Biotechnology \& Environmental Sciences 6

31. IAMME (2002): Asean marine water quality criteria adopted by the ASEAN Environment Ministers at the 7th Informal ASEAN Ministerial Meeting on the Environment (IAMME) in Vientiane, Lao PDR

32. Iftekhar MS, Islam MR (2004): Managing mangroves in Bangladesh: A strategy analysis. Journal of Coastal Conservation 10, 139-146

33. ILIE M, MARINESCU F, SZEP R, GHIȚA G, DEAK G, ANGHEL A-M, PETRESCU A, URIȚESCU B (2017): Ecological risk assessment of heavy metals in surface sediments from the Danube river. Carpathian Journal of Earth and Environmental Sciences 12, 437-445

34. Islam SMD, Bhuiyan, M.A.H. (2018): Sundarbans mangrove forest of Bangladesh: causes of degradation and sustainable management options. Environ. Sustainability 1, 113-131

35. Kawo NS, Karuppannan S (2018): Groundwater quality assessment using water quality index and GIS technique in Modjo River Basin, central Ethiopia. Journal of African Earth Sciences 147, 300-311

36. Kayode O. Adebowale, Agunbiade FO, Olu-Owolabi BI (2009): Trace Metal Concentrations, Site Variations and Partitioning Pattern in Water and Bottom Sediments from Coastal Area: A Case Study of Ondo Coast, Nigeria. Environmental Research Journal 3, 46-59

37. Kibria G, Hossain MM, Mallick D, Lau TC, Wu R (2016): Monitoring of metal pollution in waterways across Bangladesh and ecological and public health implications of pollution. Chemosphere 165, 1-9

38. Kim JH, Gibb HJ, Howe PD (2006): Cobalt and inorganic cobalt compounds: Concise international chemical assessment document ; 69. United Nations Environment Programme, the International Labour Organization, and the World Health Organization

39. Krishnendu Mukherjee, Chakrabarty. R (2014): 350-tonne oil spill by Bangladeshi ship threatens Sunderbans, The Times of India

40. Krishnendu Mukherjee, Chakrabarty R (December 12, 2014): 350-tonne oil spill by Bangladeshi ship threatens Sunderbans. The Times of India

41. Kumar A, Ramanathan AL (2015): Speciation of selected trace metals (Fe, Mn, Cu and Zn) with depth in the sediments of Sundarban mangroves: India and Bangladesh. Journal of Soils and Sediments 15, 2476-2486 
42. Li P, Wu J, Tian R, He S, He X, Xue C, Zhang K (2018): Geochemistry, Hydraulic Connectivity and Quality Appraisal of Multilayered Groundwater in the Hongdunzi Coal Mine, Northwest China. Mine Water Environ. 37, 222-237

43. Long ER, Macdonald DD, Smith SL, Calder FD (1995): Incidence of adverse biological effects within ranges of chemical concentrations in marine and estuarine sediments. Environmental Management 19, 81-97

44. Long ER, MacDonald DD (1998): Recommended Uses of Empirically Derived, Sediment Quality Guidelines for Marine and Estuarine Ecosystems. Human and Ecological Risk Assessment: An International Journal 4, 1019-1039

45. S. Praveena, Radojevic M, Abdullah MH (2007): The Assessment of Mangrove Sediment Quality in Mengkabong Lagoon: An Index Analysis Approach. International Journal of Environmental \& Science Education 2, 60-68

46. McCready S, Birch GF, Long ER (2006): Metallic and organic contaminants in sediments of Sydney Harbour, Australia and vicinity - A chemical dataset for evaluating sediment quality guidelines. Environment International 32, 455-465

47. McPherson CA, P.M. Chapman, Vigers GA, Ong. KS (1999): ASEAN Marine Water Quality Criteria: Contextual Framework, Principles, Methodology and Criteria for 18 Parameters. ASEAN Marine Environmental Quality Criteria - Working Group (AMEQCWG), ASEAN-Canada Cooperative Programme on Marine Science - Phase II (CPMS-II). . EVS Environment Consultants, North Vancouver and Department of Fisheries, Malaysia., 568

48. Mertler CA, Vannatta R.A. (2005): Advanced and Multivariate statistical methods: Practical application and interpretation (3rd ed). Pyrczak Publishing (1845), $120 \mathrm{pp}$

49. Mihaela Ilie FM, Szép Robert, Bogdan Urițescu (2017): Ecological risk assessment of heavy metals in surface sediments from the Danube River. Carpathian Journal of Earth and Environmental Sciences 12, 437-445

50. Mission JUNGoB (2014): Sundarban oil spill assessment. 1-106

51. Mohiuddin KM, Zakir HM, Otomo K, Sharmin S, Shikazono N (2010): Geochemical distribution of trace metal pollutants in water and sediments of downstream of an urban river. International Journal of Environmental Science \& Technology 7, 17-28

52. Mustafa AD, Juahir, H., Yunus, K., Amran, M.A., Hasnam, C.N.C., Azaman, F., Abidin, I.Z., Azmee, S.H., Sulaiman, N.H. (2015): Oil spill related heavy metal: A review. Malaysian Journal of Analytical Sciences 19, $1348-1360$

53. Nolting RF, Ramkema A, Everaarts JM (1999): The geochemistry of Cu, Cd, Zn, Ni and Pb in sediment cores from the continental slope of the Banc d'Arguin (Mauritania). Continental Shelf Research 19, 665-691

54. Öğlü B, Yorulmaz B, Genç TO, Yilmaz F (2015): The assessment of heavy metal content by using bioaccumulation indices in European chub, Squalius cephalus (Linnaeus, 1758). Carpathian Journal of Earth and Environmental Sciences 10, 85 - 94

55. Ohta A, Imai N, Terashima S, Tachibana Y, Ikehara K, Okai T, Ujiie-Mikoshiba M, Kubota R (2007): Elemental distribution of coastal sea and stream sediments in the island-arc region of Japan and mass transfer processes from terrestrial to marine environments. Applied Geochemistry 22, $2872-2891$

56. Ojekunle OZ, Ojekunle OV, Adeyemi AA, Taiwo AG, Sangowusi OR, Taiwo AM, Adekitan AA (2016): Evaluation of surface water quality indices and ecological risk assessment for heavy metals in scrap yard neighbourhood. SpringerPlus 5,560

57. Persaud DR, R. Jaagumagi, Hayton A (1993): Guidelines for the protection and management of aquatic sediments in Ontario. Standards Development Branch. Ontario Ministry of Environment and Energy. Toronto, Canada.

58. Prescott LM., J.P. H, D.A. K (1999): The influence of environmental factors on growth. McGraw-Hill Companies, Inc., USA 4th Edition, 123-132

59. Rahman M (2005): Sundarban ecologically critical area, Bangladesh. The Whitley Fund for Nature

60. Rahman MS, Hossain, M.B., Babu, S.M.O.F., Rahman, M., Ahmed, A.S.S., Jolly, Y.N., Choudhury, T.R., Begum, B.A., Kabir, J., Akter, S. (2019): Source of metal contamination in sediment, their ecological risk, and phytoremediation ability of the studied mangrove plants in ship breaking area, Bangladesh. Mar. Pollut. Bull. 141, 137-146

61. Rahman MS, Molla, A.H., Saha, N., Al-Reza, S.M. (2014): Assessment of anthropogenic influence on heavy metals contamination in the aquatic ecosystem components: water, sediment, and fish. Soil Sediment Contam 23, 353-373

62. Raknuzzaman M, Ahmed MK, Islam MS, Habibullah-Al-Mamun M, Tokumura M, Sekine M, Masunaga S (2016): Assessment of Trace Metals in Surface Water and Sediment Collected from Polluted Coastal Areas of Bangladesh. Journal of Water and Environment Technology 14, 247-259

63. Rezwan (2014): Massive Oil Spill Threatens Bangladesh's Sundarbans". Retrieved Global Voices Online

64. Roy P (April 25, 2018): Bangladesh allows nearly 200 polluting factories near Sundarbans. the thirdpole.net

65. Rule JH (1986): Assessment of trace element geochemistry of Hampton Roads harbor and lower Chesapeake Bay area sediments. Environmental Geology and Water Sciences 8, 209-219

66. Saha N, Rahman, M.S., Ahmed, M.B., Zhou, J.L. (2017): Industrial metal pollution in water and probabilistic assessment of human health risk. J. Environ. Manage. 185, 70-78

67. Saleh A, Al-Ruwaih F, Shehata M (1999): Hydrogeochemical processes operating within the main aquifers of Kuwait. Journal of Arid Environments 42, 195-209

68. Seidensticker J, Abdulhađīi Ma (1983): The Sundarbans Wildlife Management Plan : conservation in the Bangladesh coastal zone 113-120

69. Simeonov V, Stratis JA, Samara C, Zachariadis G, Voutsa D, Anthemidis A, Sofoniou M, Kouimtzis T (2003): Assessment of the surface water quality in Northern Greece. Water Research 37, 4119-4124

70. Sinex SA, Helz GR (1981): Regional geochemistry of trace elements in Chesapeake Bay sediments. Environmental Geology 3, 315-323

71. Singh M, Muller, G., \& Singh, I. B. (2002): Heavy metals in freshly deposited stream sediments of rivers associated with urbanization of the Ganga plain, India. Water, Air, Soil Pollut. 141, 35-54

Page $12 / 24$ 
72. Smith CJ, Oster JD, Sposito G (2015): Potassium and magnesium in irrigation water quality assessment. Agricultural Water Management 157, 59-64

73. Smith SL, MacDonald DD, Keenleyside KA, Ingersoll CG, Jay Field L (1996): A Preliminary Evaluation of Sediment Quality Assessment Values for Freshwater Ecosystems. Journal of Great Lakes Research 22, 624-638

74. Subramani T, Elango L, Damodarasamy SR (2005): Groundwater quality and its suitability for drinking and agricultural use in Chithar River Basin, Tamil Nadu, India. Environmental Geology 47, 1099-1110

75. Tamasi G, Cini R (2004): Heavy metals in drinking waters from Mount Amiata (Tuscany, Italy). Possible risks from arsenic for public health in the Province of Siena. Sci. Total Environ. 327, 41-51

76. Tomlinson DL, Wilson JG, Harris CR, Jeffrey DW (1980): Problems in the assessment of heavy-metal levels in estuaries and the formation of a pollution index. Helgoländer Meeresuntersuchungen 33, 566-575

77. USDA-NRCS (2014): Soil electrical conductivity. United States Department of Agriculture-Natural Resource Conservation Service

78. USEPA (2017): National Recommended Water Quality Criteria - Aquatic Life Criteria Table. United States Environmental Protection Agency

79. Ustaoğlua F, Islam, M.S. (2020): Potential toxic elements in sediment of some rivers at Giresun, Northeast Turkey: A preliminary assessment for ecotoxicological status and health risk. Ecol. Indic. 113, 106237.

80. Wang J, Jiang Y, Sun J, She J, Yin M., Fang F, Xiao T, Song G, Liu J (2020): Geochemical transfer of cadmium in river sediments near a lead-zinc smelter. Ecotoxicol. Environ. Saf. 196, 110529

81. WCS (2020): Irrawaddy Dolphin, Wildlife Conservation Society (WCS), a New York-based organization

82. Wetzel RG (2001): Rivers and lakes-their distribution, origins and forms. In: Wetzel RG (Editor), Limnology (Third Edition). Academic Press, San Diego, pp. $15-42$

83. WHO (2011): Guidelines for drinking-water quality (4th Edition). World Health Organization

84. Wu J, Sun Z (2016): Evaluation of Shallow Groundwater Contamination and Associated Human Health Risk in an Alluvial Plain Impacted by Agricultural and Industrial Activities, Mid-west China. Exposure Health 8, 311-329

\section{Tables}

Table 1. Sampling point information at Sela River, Sundarbans area, Khulna, Bangladesh

\begin{tabular}{|llllll|}
\hline Sampling & Station Code & Sediment & Water & Latitude & Longitude \\
Station No & & Sample Code & Sample Code & $(\mathrm{N})$ & (E) \\
\hline Station-1 & P1 & S1 & W1 & 22.27626 & 89.71546 \\
\hline Station-2 & P2 & S2 & - & 22.27062 & 89.73529 \\
\hline Station-3 & P3 & S3 & W2 & 22.25852 & 89.72501 \\
\hline Station-4 & P4 & S4 & - & 22.24484 & 89.71967 \\
\hline Station-5 & P5 & S5 & W3 & 22.23173 & 89.70986 \\
\hline Station-6 & P6 & S6 & - & 22.2176 & 89.69896 \\
\hline Station-7 & P7 & S7 & W4 & 22.20146 & 89.69024 \\
\hline Station-8 & P8 & S8 & - & 22.18782 & 89.69512 \\
\hline Station-9 & P9 & S9 & W5 & 22.1761 & 89.69256 \\
\hline Station-10 & P10 & S10 & - & 22.16297 & 89.69692 \\
\hline Station-11 & P11 & S11 & W6 & 22.14379 & 89.70237 \\
\hline Station-12 & P12 & S12 & - & 22.1034 & 89.70891 \\
\hline Station-13 & P13 & S13 & W7 & 22.07008 & 89.70673 \\
\hline Station-14 & P14 & S14 & - & 22.05391 & 89.67403 \\
\hline Station-15 & P15 & S15 & W8 & 22.03775 & 89.69801 \\
\hline Station-16 & P16 & S16 & - & 22.01855 & 89.6991 \\
\hline Station-17 & P17 & S17 & W9 & 21.99531 & 89.68384 \\
\hline Station-18 & P18 & S18 & - & 21.97307 & 89.68602 \\
\hline Station-19 & P19 & S19 & W10 & 21.95184 & 89.69147 \\
\hline Station-20 & P20 & S20 & - & 21.90938 & 89.6773 \\
\hline & & & & & \\
\hline
\end{tabular}

Table 2. The assessment indices used in this study for evaluation of the measured metals for the contamination in Sela River, Sundarbans. 


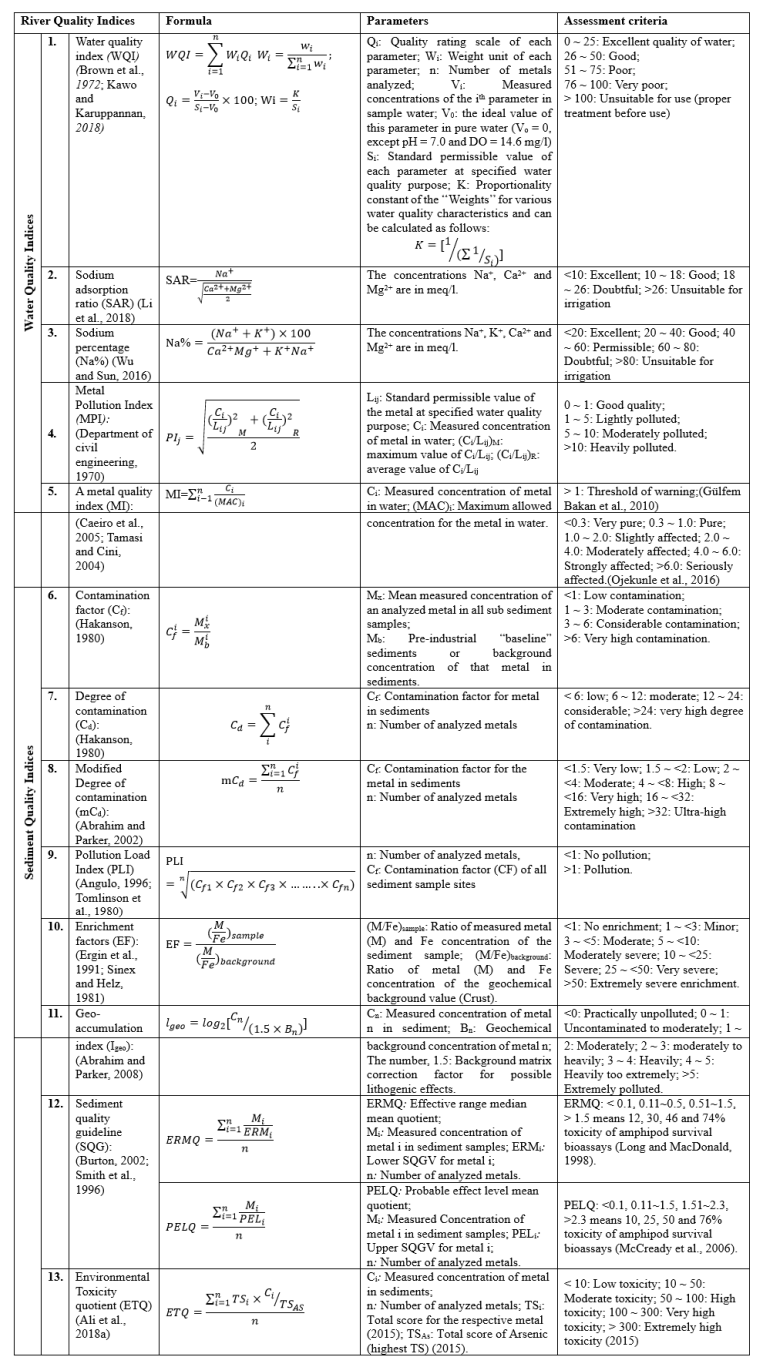

Table 3. Physio-chemical properties of Sela River water

\begin{tabular}{|c|c|c|c|c|c|}
\hline Sample sites & $\begin{array}{l}\text { Temperature, } \\
{ }^{\circ} \mathrm{C}\end{array}$ & $\begin{array}{l}\text { Dissolved Oxygen (DO), } \\
\mathrm{mg} / \mathrm{I}\end{array}$ & $\mathrm{pH}$ & $\begin{array}{l}\text { Electrical conductivity (EC), } \\
\mu \mathrm{s} / \mathrm{cm}\end{array}$ & $\begin{array}{l}\text { Total Dissolved Solids } \\
\text { (TDS), } \\
\mathrm{mg} / \mathrm{l}\end{array}$ \\
\hline W1 & 23.8 & 9.5 & 8.46 & 3370 & 2370 \\
\hline W2 & 23 & 5.2 & 8.57 & 3300 & 2320 \\
\hline W3 & 23.8 & 4.6 & 8.20 & 3520 & 2610 \\
\hline W4 & 24 & 5.2 & 8.10 & 3800 & 2690 \\
\hline W5 & 24.5 & 4.6 & 8.03 & 3510 & 2430 \\
\hline W6 & 24.6 & 6.8 & 7.45 & 3200 & 2250 \\
\hline W7 & 24.2 & 6 & 7.72 & 3200 & 2250 \\
\hline W8 & 23.8 & 7.7 & 8.04 & 3590 & 2550 \\
\hline W9 & 24.4 & 4.8 & 8.03 & 3520 & 2590 \\
\hline W10 & 24.5 & 4.5 & 8.00 & 3500 & 2600 \\
\hline Average & 24.06 & 5.89 & 8.06 & 3451 & 2466 \\
\hline Drinking (WHO, 2011) & 20.0 & 5 & $\begin{array}{l}6- \\
8.5\end{array}$ & 1000 & 600 \\
\hline $\begin{array}{l}\text { Irrigation (Ayers and Westcot, } \\
\text { 1994) }\end{array}$ & - & - & 8.5 & 3000 & 2000 \\
\hline Aquatic life (McPherson et al., 1999) & $\begin{array}{l}\text { Ambient } \\
\text { tempearture }+2^{\circ} \mathrm{C}\end{array}$ & $5-6$ & $6-9$ & 3000 & $\begin{array}{l}1000 \\
\text { (Boyd, 2000) }\end{array}$ \\
\hline
\end{tabular}


Table 4. The concentration of metals ( $\mu \mathrm{g} / \mathrm{L})$ in Sundarbans Sela River water measured by Flame Atomic Absorption Spectrometer (FAAS), Hydride Generation AAS (only for As) and Cold-Vapor AAS (only for $\mathrm{Hg}$ ).

\begin{tabular}{|c|c|c|c|c|c|c|c|c|c|c|c|c|c|c|}
\hline \multicolumn{2}{|l|}{$\begin{array}{l}\text { Sample } \\
\text { Sites }\end{array}$} & $\begin{array}{l}\mathrm{Pb} \\
(\mu \mathrm{g} / \mathrm{L})\end{array}$ & $\begin{array}{l}\mathrm{Cd} \\
(\mu \mathrm{g} / \mathrm{L})\end{array}$ & $\begin{array}{l}\mathrm{Cr} \\
(\mu \mathrm{g} / \mathrm{L})\end{array}$ & $\begin{array}{l}\text { Co } \\
(\mu g / L)\end{array}$ & $\begin{array}{l}\mathrm{Cu} \\
(\mu \mathrm{g} / \mathrm{L})\end{array}$ & $\begin{array}{l}\mathrm{Ni} \\
(\mu \mathrm{g} / \mathrm{L})\end{array}$ & $\begin{array}{l}\mathrm{Fe} \\
(\mu \mathrm{g} / \mathrm{L})\end{array}$ & $\begin{array}{l}M n \\
(\mu g / L)\end{array}$ & $\begin{array}{l}\mathrm{Zn} \\
(\mu \mathrm{g} / \mathrm{L})\end{array}$ & $\begin{array}{l}\mathrm{Ca} \\
(\mathrm{mg} / \mathrm{L})\end{array}$ & $\underset{(\mathrm{mg} / \mathrm{L})}{\mathrm{Mg}}$ & $\begin{array}{l}\mathrm{Na} \\
(\mathrm{mg} / \mathrm{L})\end{array}$ & $\begin{array}{l}\mathrm{K} \\
(\mathrm{mg} / \mathrm{L})\end{array}$ \\
\hline \multicolumn{2}{|l|}{ W1 } & $\begin{array}{l}85.00 \\
\pm 1.87\end{array}$ & $\begin{array}{l}20.50 \\
\pm 0.10\end{array}$ & $\begin{array}{l}26.40 \\
\pm 0.98\end{array}$ & $\begin{array}{l}105.40 \\
\pm 5\end{array}$ & $\begin{array}{l}37.50 \\
\pm 0.15\end{array}$ & $\begin{array}{l}96.70 \\
\pm 3.38\end{array}$ & $\begin{array}{l}17.00 \\
\pm 0.02\end{array}$ & $\begin{array}{l}104.26 \\
\pm 0.63\end{array}$ & $\begin{array}{l}18.63 \\
\pm 0.80\end{array}$ & $\begin{array}{l}89.50 \\
\pm 1.52\end{array}$ & $\begin{array}{l}309.06 \\
\pm 0.62\end{array}$ & $\begin{array}{l}47.38 \\
\pm 0.24\end{array}$ & $\begin{array}{l}90.72 \pm \\
0.18\end{array}$ \\
\hline \multicolumn{2}{|l|}{ W2 } & $\begin{array}{l}87.00 \\
\pm 5.39\end{array}$ & $\begin{array}{l}19.60 \\
\pm 0.18\end{array}$ & $\begin{array}{l}28.60 \\
\pm 0.74\end{array}$ & $\begin{array}{l}95.60 \\
\pm 4.06\end{array}$ & $\begin{array}{l}17.80 \\
\pm 0.66\end{array}$ & $\begin{array}{l}90.00 \\
\pm 1.80\end{array}$ & $\begin{array}{l}33.00 \\
\pm 0.03\end{array}$ & $\begin{array}{l}18.88 \\
\pm 0.34\end{array}$ & $\begin{array}{l}20.88 \\
\pm 1.34\end{array}$ & $\begin{array}{l}91.40 \\
\pm 1.83\end{array}$ & $\begin{array}{l}280.78 \\
\pm 3.93\end{array}$ & $\begin{array}{l}270.55 \\
\pm 1.35\end{array}$ & $\begin{array}{l}31.14 \pm \\
1.09\end{array}$ \\
\hline \multicolumn{2}{|l|}{ W3 } & $\begin{array}{l}133.00 \\
\pm 3.33\end{array}$ & $\begin{array}{l}51.50 \\
\pm 1.39\end{array}$ & $\begin{array}{l}31.90 \\
\pm 0.93\end{array}$ & $\begin{array}{l}185.90 \\
\pm 6\end{array}$ & $\begin{array}{l}31.10 \\
\pm \\
1.37\end{array}$ & $\begin{array}{l}182.30 \\
\pm 1.09\end{array}$ & $\begin{array}{l}111.00 \\
\pm 0.11\end{array}$ & $\begin{array}{l}49.18 \\
\pm 1.13\end{array}$ & $\begin{array}{l}35.42 \\
\pm 0.85\end{array}$ & $\begin{array}{l}171.60 \\
\pm 0.17\end{array}$ & $\begin{array}{l}575.70 \\
\pm 3.45\end{array}$ & $\begin{array}{l}32.25 \\
\pm 0.16\end{array}$ & $\begin{array}{l}216.35 \\
2.60\end{array}$ \\
\hline \multicolumn{2}{|l|}{ W4 } & $\begin{array}{l}20.00 \\
\pm 2.56\end{array}$ & $\begin{array}{l}18.50 \\
\pm 0.41\end{array}$ & $\begin{array}{l}23.30 \\
\pm 0.63\end{array}$ & $\begin{array}{l}130.90 \\
\pm 8\end{array}$ & $\begin{array}{l}20.50 \\
\pm 0.14\end{array}$ & $\begin{array}{l}79.70 \\
\pm 0.32\end{array}$ & $\begin{array}{l}83.00 \\
\pm 0.08\end{array}$ & $\begin{array}{l}36.52 \\
\pm 2.05\end{array}$ & $\begin{array}{l}26.72 \\
\pm 0.80\end{array}$ & $\begin{array}{l}97.70 \\
\pm 0.29\end{array}$ & $\begin{array}{l}270.68 \\
\pm 1.89\end{array}$ & $\begin{array}{l}53.82 \\
\pm 0.27\end{array}$ & $\begin{array}{l}107.59 \\
0.11\end{array}$ \\
\hline \multicolumn{2}{|l|}{ W5 } & $\begin{array}{l}20.05 \\
\pm 3.00\end{array}$ & $\begin{array}{l}18.30 \\
\pm 0.6\end{array}$ & $\begin{array}{l}53.30 \\
\pm 0.43\end{array}$ & $\begin{array}{l}105.10 \\
\pm 5.6\end{array}$ & $\begin{array}{l}28.30 \\
\pm 2.18\end{array}$ & $\begin{array}{l}165.30 \\
\pm 4.30\end{array}$ & $\begin{array}{l}106.00 \\
\pm 0.11\end{array}$ & $\begin{array}{l}25.68 \\
\pm 1.77\end{array}$ & $\begin{array}{l}36.66 \\
\pm 0.40\end{array}$ & $\begin{array}{l}193.00 \\
\pm 0.58\end{array}$ & $\begin{array}{l}666.60 \\
\pm 2.67\end{array}$ & $\begin{array}{l}326.35 \\
\pm 1.63\end{array}$ & $\begin{array}{l}223.15 \\
2.01\end{array}$ \\
\hline \multicolumn{2}{|l|}{ W6 } & $\begin{array}{l}148.00 \\
\pm 5.48\end{array}$ & $\begin{array}{l}53.60 \\
\pm 2.47\end{array}$ & $\begin{array}{l}39.20 \\
\pm 0.47\end{array}$ & $\begin{array}{l}163.60 \\
\pm 8\end{array}$ & $\begin{array}{l}23.80 \\
\pm 2.45\end{array}$ & $\begin{array}{l}217.80 \\
\pm 2.40\end{array}$ & $\begin{array}{l}99.00 \\
\pm 0.10\end{array}$ & $\begin{array}{l}43.76 \\
\pm 0.22\end{array}$ & $\begin{array}{l}37.54 \\
\pm 0.90\end{array}$ & $\begin{array}{l}170.10 \\
\pm 0.34\end{array}$ & $\begin{array}{l}566.61 \\
\pm 3.97\end{array}$ & $\begin{array}{l}38.88 \\
\pm 0.19\end{array}$ & $\begin{array}{l}189.61 \\
0.19\end{array}$ \\
\hline \multicolumn{2}{|l|}{ W7 } & $\begin{array}{l}89.00 \\
\pm 1.96\end{array}$ & $\begin{array}{l}18.20 \\
\pm 0.27\end{array}$ & $\begin{array}{l}28.10 \\
\pm 1.32\end{array}$ & $\begin{array}{l}103.10 \\
\pm 6\end{array}$ & $\begin{array}{l}16.70 \\
\pm 0.17\end{array}$ & $\begin{array}{l}110.90 \\
\pm 1.44\end{array}$ & $\begin{array}{l}66.00 \\
\pm 0.07\end{array}$ & $\begin{array}{l}16.03 \\
\pm 0.26\end{array}$ & $\begin{array}{l}17.06 \\
\pm 0.09\end{array}$ & $\begin{array}{l}80.60 \\
\pm 0.89\end{array}$ & $\begin{array}{l}220.18 \\
\pm 0.22\end{array}$ & $\begin{array}{l}28.78 \\
\pm 0.14\end{array}$ & $\begin{array}{l}83.16 \pm \\
0.17\end{array}$ \\
\hline \multicolumn{2}{|l|}{ W8 } & $\begin{array}{l}84.00 \\
\pm 8.01\end{array}$ & $\begin{array}{l}40.50 \\
\pm 2.06\end{array}$ & $\begin{array}{l}46.00 \\
\pm 0.46\end{array}$ & $\begin{array}{l}317.60 \\
\pm 9.9\end{array}$ & $\begin{array}{l}22.20 \\
\pm 1.69\end{array}$ & $\begin{array}{l}212.80 \\
\pm 2.13\end{array}$ & $\begin{array}{l}90.00 \\
\pm 0.09\end{array}$ & $\begin{array}{l}33.39 \\
\pm 0.17\end{array}$ & $\begin{array}{l}34.30 \\
\pm 0.48\end{array}$ & $\begin{array}{l}168.60 \\
\pm 1.01\end{array}$ & $\begin{array}{l}721.14 \\
\pm 4.33\end{array}$ & $\begin{array}{l}354.60 \\
\pm 1.77\end{array}$ & $\begin{array}{l}198.50 \\
1.99\end{array}$ \\
\hline \multicolumn{2}{|l|}{ W9 } & $\begin{array}{l}98.00 \\
\pm 9.58\end{array}$ & $\begin{array}{l}45.40 \\
\pm 2.18\end{array}$ & $\begin{array}{l}45.00 \\
\pm 2.66\end{array}$ & $\begin{array}{l}294.40 \\
\pm 10\end{array}$ & $\begin{array}{l}22.40 \\
\pm 0.11\end{array}$ & $\begin{array}{l}213.60 \\
\pm 3.84\end{array}$ & $\begin{array}{l}114.00 \\
\pm 0.11\end{array}$ & $\begin{array}{l}16.48 \\
\pm 0.08\end{array}$ & $\begin{array}{l}35.65 \\
\pm 1.53\end{array}$ & $\begin{array}{l}187.80 \\
\pm 1.50\end{array}$ & $\begin{array}{l}700.94 \\
\pm 2.80\end{array}$ & $\begin{array}{l}32.99 \\
\pm 0.16\end{array}$ & $\begin{array}{l}194.55 \\
0.39\end{array}$ \\
\hline \multicolumn{2}{|l|}{ W10 } & $\begin{array}{l}73.00 \\
\pm 1.75\end{array}$ & $\begin{array}{l}20.80 \\
\pm 0.21\end{array}$ & $\begin{array}{l}24.50 \\
\pm 1.00\end{array}$ & $\begin{array}{l}102.20 \\
\pm 5\end{array}$ & $\begin{array}{l}15.30 \\
\pm 0.26\end{array}$ & $\begin{array}{l}111.60 \\
\pm 2.34\end{array}$ & $\begin{array}{l}15.00 \\
\pm 0.02\end{array}$ & $\begin{array}{l}5.57 \pm \\
0.50\end{array}$ & $\begin{array}{l}17.20 \\
\pm 0.09\end{array}$ & $\begin{array}{l}85.20 \\
\pm 2.13\end{array}$ & $\begin{array}{l}255.53 \\
\pm 2.04\end{array}$ & $\begin{array}{l}352.55 \\
\pm 1.76\end{array}$ & $\begin{array}{l}85.44 \pm \\
0.34\end{array}$ \\
\hline \multicolumn{2}{|l|}{ Minimum } & 20 & 18.2 & 23.3 & 95.6 & 15.3 & 79.7 & 15 & 5.57 & 17.06 & 80.6 & 220.18 & 28.78 & 83.16 \\
\hline \multicolumn{2}{|l|}{ Maximum } & 148 & 53.6 & 53.3 & 317.6 & 37.5 & 217.8 & 114 & 104.26 & 37.54 & 193 & 721.14 & 354.6 & 223.15 \\
\hline \multicolumn{2}{|l|}{ Mean } & $\begin{array}{l}83.71 \\
\pm 3.40\end{array}$ & $\begin{array}{l}30.7 \pm \\
1.63\end{array}$ & $\begin{array}{l}34.60 \\
\pm 0.96\end{array}$ & $\begin{array}{l}160.4 \\
\pm 7.03\end{array}$ & $\begin{array}{l}23.6 \pm \\
0.92\end{array}$ & $\begin{array}{l}148.1 \\
\pm 2.30\end{array}$ & $\begin{array}{l}73.4 \pm \\
0.07\end{array}$ & $\begin{array}{l}34.98 \\
\pm 0.72\end{array}$ & $\begin{array}{l}28.01 \\
\pm 0.73\end{array}$ & $\begin{array}{l}133.55 \\
\pm 1.03\end{array}$ & $\begin{array}{l}456.72 \\
\pm 2.59\end{array}$ & $\begin{array}{l}153.82 \\
\pm 0.77\end{array}$ & $\begin{array}{l}148.02 \\
\pm 0.91\end{array}$ \\
\hline \multirow{3}{*}{$\begin{array}{l}\text { Reference } \\
\text { lue }\end{array}$} & Drinking ${ }^{c}$ & 10 & 3 & 50 & $8^{d}$ & 2000 & 70 & 300 & 100 & 3000 & 75 & 50 & 200 & 12 \\
\hline & Irrigation ${ }^{\mathrm{e}}$ & 5000 & 10 & 100 & 50 & 200 & 200 & 5000 & 200 & 2000 & 400 & 60 & 920 & 2 \\
\hline & $\begin{array}{l}\text { Aquatic } \\
\text { life }\end{array}$ & 8.5 & 10 & 50 & $8^{\text {h }}$ & 2.9 & $52^{i}$ & - & $50^{1}$ & $50^{\mathrm{m}}$ & - & - & - & - \\
\hline \multicolumn{2}{|c|}{ Pasur River ${ }^{\mathrm{n}}$} & $\begin{array}{l}20 \sim \\
26.7\end{array}$ & $\begin{array}{l}1.20 \\
\tilde{1.97}\end{array}$ & $\begin{array}{l}44.3 \\
\tilde{5} 3.5\end{array}$ & - & - & - & - & - & - & - & - & - & - \\
\hline \multicolumn{2}{|c|}{ Bramaputra river (ref) ${ }^{\circ}$} & 110 & 1 & 10 & 200 & 120 & 440 & - & 1440 & 10 & - & - & - & - \\
\hline
\end{tabular}

Note: ${ }^{a, b}$ The measured value (MV) of $A s$ and $\mathrm{Hg}$ was found to be less than the detection limit (DL) and thus considered to be equal to the $\mathrm{DL}$, i.e., 3.0 and 0.3 $\mu \mathrm{g} /$ respectively; ${ }^{c} \mathrm{WHO}$ guideline value (WHO, 2011) was used for drinking criteria of all metals except Co; ${ }^{d, h}$ Cobalt reference values for drinking and aquatic life respectively (Kim et al., 2006); ${ }^{e}$ Guideline values used for irrigation criteria of all metals except $\mathrm{Hg}$ (Ayers and Westcot, 1994); ${ }^{\mathrm{f}} \mathrm{Hg}$ guideline value for irrigation purpose (ANZECC, 2000); ${ }^{9}$ Guideline values used for aquatic life criteria of all metals except Co, Ni, As, Fe, Mn and Zn (IAMME, 2002); ${ }^{\mathrm{k} k \mathrm{Ni}}$ and $\mathrm{Hg}$ guideline values while for survival of the aqualic life (USEPA, 2017); j, $\mathrm{m}$ As and Zn guideline values for survival of aqualic life (McPherson et al., 1999); ${ }^{\mathrm{I}} \mathrm{Mn}$

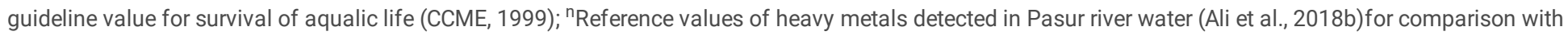
the present study; ${ }^{\circ}$ Reference values of heavy metals detected in Bramaputra river water (Bhuyan et al., 2019) for comparison with the present study.

Table 5. The results for the analysis of heavy metals concentration on a dry weight basis $(\mathrm{mg} / \mathrm{kg})$ measured in Sundarbans Sela River Sediments via Flame Atomic Absorption Spectrometer (FAAS) and Hydride Generation AAS (for metalloid Arsenic, As). 


\begin{tabular}{|c|c|c|c|c|c|c|c|c|c|c|c|c|}
\hline Sample sites & $\begin{array}{l}\mathrm{Pb}, \\
\mathrm{mg} / \mathrm{kg}\end{array}$ & $\begin{array}{l}\mathrm{Cd}, \\
\mathrm{mg} / \mathrm{kg}\end{array}$ & $\begin{array}{l}\mathrm{Cr}, \\
\mathrm{mg} / \mathrm{kg}\end{array}$ & $\begin{array}{l}\mathrm{Cu}, \\
\mathrm{mg} / \mathrm{kg}\end{array}$ & $\begin{array}{l}\mathrm{As}, \\
\mathrm{mg} / \mathrm{kg}\end{array}$ & $\begin{array}{l}\mathrm{Fe}, \\
\mathrm{mg} / \mathrm{kg}\end{array}$ & $\begin{array}{l}\mathrm{Mn}, \\
\mathrm{mg} / \mathrm{kg}\end{array}$ & $\begin{array}{l}\mathrm{Zn}, \\
\mathrm{mg} / \mathrm{kg}\end{array}$ & $\begin{array}{l}\mathrm{Ca}, \\
\mathrm{mg} / \mathrm{kg}\end{array}$ & $\begin{array}{l}\mathrm{Mg} \\
\mathrm{mg} / \mathrm{kg}\end{array}$ & $\begin{array}{l}\mathrm{Na}, \\
\mathrm{mg} / \mathrm{kg}\end{array}$ & $\begin{array}{l}\mathrm{K}, \\
\mathrm{mg} / \mathrm{kg}\end{array}$ \\
\hline S1 & $\begin{array}{l}25.04 \pm \\
1.70\end{array}$ & $\begin{array}{l}1.02 \pm \\
0.02\end{array}$ & $\begin{array}{l}44.05 \pm \\
0.44\end{array}$ & $\begin{array}{l}34.80 \pm \\
1.15\end{array}$ & $\begin{array}{l}3.28 \pm \\
0.03\end{array}$ & $\begin{array}{l}29934 \pm \\
150\end{array}$ & $\begin{array}{l}501.02 \pm \\
1.00\end{array}$ & $\begin{array}{l}73.64 \pm \\
0.22\end{array}$ & $\begin{array}{l}2126 \pm \\
17\end{array}$ & $\begin{array}{l}14348 \pm \\
115\end{array}$ & $\begin{array}{l}1764 \pm \\
5\end{array}$ & $\begin{array}{l}4569 \\
\pm 27\end{array}$ \\
\hline S2 & $\begin{array}{l}19.00 \pm \\
0.44\end{array}$ & $\begin{array}{l}1.10 \pm \\
0.03\end{array}$ & $\begin{array}{l}37.25 \pm \\
0.30\end{array}$ & $\begin{array}{l}29.72 \pm \\
1.99\end{array}$ & $\begin{array}{l}2.78 \pm \\
0.02\end{array}$ & $\begin{array}{l}24745 \pm \\
124\end{array}$ & $\begin{array}{l}408.64 \pm \\
1.23\end{array}$ & $\begin{array}{l}63.25 \pm \\
0.25\end{array}$ & $\begin{array}{l}4265 \pm \\
13\end{array}$ & $\begin{array}{l}13686 \pm \\
82\end{array}$ & $\begin{array}{l}2719 \pm \\
3\end{array}$ & $\begin{array}{l}3913 \\
\pm 63\end{array}$ \\
\hline S3 & $\begin{array}{l}21.54 \pm \\
1.12\end{array}$ & $\begin{array}{l}1.05 \pm \\
0.01\end{array}$ & $\begin{array}{l}40.38 \pm \\
0.04\end{array}$ & $\begin{array}{l}33.33 \pm \\
0.37\end{array}$ & $\begin{array}{l}2.23 \pm \\
0.03\end{array}$ & $\begin{array}{l}27325 \pm \\
137\end{array}$ & $\begin{array}{l}496.36 \pm \\
1.49\end{array}$ & $\begin{array}{l}69.68 \pm \\
1.32\end{array}$ & $\begin{array}{l}3522 \pm \\
46\end{array}$ & $\begin{array}{l}12498 \pm \\
50\end{array}$ & $\begin{array}{l}2441 \pm \\
2\end{array}$ & $\begin{array}{l}4235 \\
\pm 34\end{array}$ \\
\hline S4 & $\begin{array}{l}19.50 \pm \\
0.55\end{array}$ & $\begin{array}{l}1.15 \pm \\
0.01\end{array}$ & $\begin{array}{l}37.30 \pm \\
0.34\end{array}$ & $\begin{array}{l}31.64 \pm \\
0.57\end{array}$ & $\begin{array}{l}2.67 \pm \\
0.09\end{array}$ & $\begin{array}{l}28785 \pm \\
144\end{array}$ & $\begin{array}{l}350.58 \pm \\
1.75\end{array}$ & $\begin{array}{l}66.40 \pm \\
0.40\end{array}$ & $\begin{array}{l}1195 \pm \\
6\end{array}$ & $\begin{array}{l}13029 \pm \\
91\end{array}$ & $\begin{array}{l}2368 \pm \\
38\end{array}$ & $\begin{array}{l}4317 \\
\pm \\
4\end{array}$ \\
\hline S5 & $\begin{array}{l}20.04 \pm \\
0.38\end{array}$ & $\begin{array}{l}1.05 \pm \\
0.01\end{array}$ & $\begin{array}{l}40.38 \pm \\
0.81\end{array}$ & $\begin{array}{l}35.25 \pm \\
1.16\end{array}$ & $\begin{array}{l}3.00 \pm \\
0.02\end{array}$ & $\begin{array}{l}20240 \pm \\
101\end{array}$ & $\begin{array}{l}453.34 \pm \\
0.45\end{array}$ & $\begin{array}{l}70.76 \pm \\
0.42\end{array}$ & $\begin{array}{l}1488 \pm \\
1\end{array}$ & $\begin{array}{l}11942 \pm \\
143\end{array}$ & $\begin{array}{l}1514 \pm \\
9\end{array}$ & $\begin{array}{l}4028 \\
\pm 28\end{array}$ \\
\hline S6 & $\begin{array}{l}22.34 \pm \\
1.61\end{array}$ & $\begin{array}{l}1.17 \pm \\
0.04\end{array}$ & $\begin{array}{l}39.39 \pm \\
0.43\end{array}$ & $\begin{array}{l}31.84 \pm \\
1.21\end{array}$ & $\begin{array}{l}3.28 \pm \\
0.11\end{array}$ & $\begin{array}{l}29739 \pm \\
149\end{array}$ & $\begin{array}{l}476.59 \pm \\
5.24\end{array}$ & $\begin{array}{l}69.49 \pm \\
0.42\end{array}$ & $\begin{array}{l}2173 \pm \\
17\end{array}$ & $\begin{array}{l}13280 \pm \\
159\end{array}$ & $\begin{array}{l}1670 \pm \\
5\end{array}$ & $\begin{array}{l}4010 \\
\pm 28\end{array}$ \\
\hline S7 & $\begin{array}{l}30.34 \pm \\
0.39\end{array}$ & $\begin{array}{l}2.28 \pm \\
0.04\end{array}$ & $\begin{array}{l}44.50 \pm \\
0.27\end{array}$ & $\begin{array}{l}35.90 \pm \\
0.29\end{array}$ & $\begin{array}{l}3.43 \pm \\
0.04\end{array}$ & $\begin{array}{l}29622 \pm \\
148\end{array}$ & $\begin{array}{l}507.69 \pm \\
6.60\end{array}$ & $\begin{array}{l}71.20 \pm \\
0.50\end{array}$ & $\begin{array}{l}2508 \pm \\
15\end{array}$ & $\begin{array}{l}12768 \pm \\
243\end{array}$ & $\begin{array}{l}1485 \pm \\
12\end{array}$ & $\begin{array}{l}4582 \\
\pm 73\end{array}$ \\
\hline S8 & $\begin{array}{l}30.00 \pm \\
0.06\end{array}$ & $\begin{array}{l}2.35 \pm \\
0.04\end{array}$ & $\begin{array}{l}44.40 \pm \\
0.71\end{array}$ & $\begin{array}{l}35.52 \pm \\
0.60\end{array}$ & $\begin{array}{l}3.36 \pm \\
0.04\end{array}$ & $\begin{array}{l}23735 \pm \\
119\end{array}$ & $\begin{array}{l}516.26 \pm \\
3.10\end{array}$ & $\begin{array}{l}72.94 \pm \\
1.09\end{array}$ & $2345 \pm$ & $\begin{array}{l}11817 \pm \\
83\end{array}$ & $\begin{array}{l}1529 \pm \\
3\end{array}$ & $\begin{array}{l}4405 \\
\pm 75\end{array}$ \\
\hline S9 & $\begin{array}{l}26.57 \pm \\
0.32\end{array}$ & $\begin{array}{l}2.11 \pm \\
0.01\end{array}$ & $\begin{array}{l}34.29 \pm \\
0.48\end{array}$ & $\begin{array}{l}29.08 \pm \\
1.31\end{array}$ & $\begin{array}{l}2.44 \pm \\
0.04\end{array}$ & $\begin{array}{l}31393 \pm \\
157\end{array}$ & $\begin{array}{l}312.83 \pm \\
4.07\end{array}$ & $\begin{array}{l}66.38 \pm \\
0.20\end{array}$ & $\begin{array}{l}777 \pm \\
15\end{array}$ & $\begin{array}{l}11646 \pm \\
35\end{array}$ & $\begin{array}{l}1517 \pm \\
26\end{array}$ & $\begin{array}{l}4367 \\
\pm 39\end{array}$ \\
\hline S10 & $\begin{array}{l}30.08 \pm \\
0.15\end{array}$ & $\begin{array}{l}2.21 \pm \\
0.04\end{array}$ & $\begin{array}{l}37.55 \pm \\
0.19\end{array}$ & $\begin{array}{l}34.27 \pm \\
1.82\end{array}$ & $\begin{array}{l}3.31 \pm \\
0.03\end{array}$ & $\begin{array}{l}28355 \pm \\
142\end{array}$ & $\begin{array}{l}472.28 \pm \\
2.36\end{array}$ & $\begin{array}{l}71.86 \pm \\
0.29\end{array}$ & $\begin{array}{l}2321 \pm \\
49\end{array}$ & $\begin{array}{l}13114 \pm \\
79\end{array}$ & $\begin{array}{l}2202 \pm \\
33\end{array}$ & $\begin{array}{l}4331 \\
\pm 13\end{array}$ \\
\hline S11 & $\begin{array}{l}31.61 \pm \\
0.03\end{array}$ & $\begin{array}{l}2.31 \pm \\
0.06\end{array}$ & $\begin{array}{l}32.11 \pm \\
0.26\end{array}$ & $\begin{array}{l}31.99 \pm \\
0.74\end{array}$ & $\begin{array}{l}3.44 \pm \\
0.10\end{array}$ & $\begin{array}{l}28374 \pm \\
142\end{array}$ & $\begin{array}{l}366.44 \pm \\
3.30\end{array}$ & $\begin{array}{l}75.44 \pm \\
0.60\end{array}$ & $\begin{array}{l}326 \pm \\
3\end{array}$ & $\begin{array}{l}26550 \pm \\
80\end{array}$ & $\begin{array}{l}75496 \pm \\
302\end{array}$ & $\begin{array}{l}5373 \\
\pm 43\end{array}$ \\
\hline $\mathrm{S} 12$ & $\begin{array}{l}28.07 \pm \\
0.73\end{array}$ & $\begin{array}{l}1.05 \pm \\
0.02\end{array}$ & $\begin{array}{l}43.01 \pm \\
0.39\end{array}$ & $\begin{array}{l}34.28 \pm \\
1.54\end{array}$ & $\begin{array}{l}4.09 \pm \\
0.03\end{array}$ & $\begin{array}{l}32406 \pm \\
162\end{array}$ & $\begin{array}{l}484.94 \pm \\
5.33\end{array}$ & $\begin{array}{l}76.37 \pm \\
0.53\end{array}$ & $\begin{array}{l}1028 \pm \\
37\end{array}$ & $\begin{array}{l}16355 \pm \\
65\end{array}$ & $\begin{array}{l}29419 \pm \\
59\end{array}$ & $\begin{array}{l}6056 \\
\pm 24\end{array}$ \\
\hline S13 & $\begin{array}{l}31.06 \pm \\
0.06\end{array}$ & $\begin{array}{l}1.40 \pm \\
0.02\end{array}$ & $\begin{array}{l}49.45 \pm \\
0.49\end{array}$ & $\begin{array}{l}36.93 \pm \\
0.41\end{array}$ & $\begin{array}{l}3.93 \pm \\
0.10\end{array}$ & $\begin{array}{l}40481 \pm \\
202\end{array}$ & $\begin{array}{l}568.37 \pm \\
3.98\end{array}$ & $\begin{array}{l}84.08 \pm \\
0.67\end{array}$ & $\begin{array}{l}1022 \pm \\
37\end{array}$ & $\begin{array}{l}15737 \pm \\
110\end{array}$ & $\begin{array}{l}12650 \pm \\
215\end{array}$ & $\begin{array}{l}6677 \\
\pm \\
7\end{array}$ \\
\hline S14 & $\begin{array}{l}29.54 \pm \\
0.56\end{array}$ & $\begin{array}{l}1.20 \pm \\
0.01\end{array}$ & $\begin{array}{l}43.51 \pm \\
0.57\end{array}$ & $\begin{array}{l}36.44 \pm \\
0.33\end{array}$ & $\begin{array}{l}3.96 \pm \\
0.03\end{array}$ & $\begin{array}{l}36408 \pm \\
182\end{array}$ & $\begin{array}{l}572.85 \pm \\
3.44\end{array}$ & $\begin{array}{l}82.80 \pm \\
0.91\end{array}$ & $\begin{array}{l}926 \pm \\
32\end{array}$ & $\begin{array}{l}14665 \pm \\
117\end{array}$ & $\begin{array}{l}13400 \pm \\
161\end{array}$ & $\begin{array}{l}5874 \\
\pm 29\end{array}$ \\
\hline S15 & $\begin{array}{l}30.02 \pm \\
0.90\end{array}$ & $\begin{array}{l}1.40 \pm \\
0.02\end{array}$ & $\begin{array}{l}41.33 \pm \\
0.54\end{array}$ & $\begin{array}{l}33.87 \pm \\
0.81\end{array}$ & $\begin{array}{l}3.62 \pm \\
0.01\end{array}$ & $\begin{array}{l}31836 \pm \\
159\end{array}$ & $\begin{array}{l}537.94 \pm \\
4.84\end{array}$ & $\begin{array}{l}80.84 \pm \\
0.57\end{array}$ & $\begin{array}{l}911 \pm \\
11\end{array}$ & $\begin{array}{l}14503 \pm \\
58\end{array}$ & $\begin{array}{l}9955 \pm \\
100\end{array}$ & $\begin{array}{l}5498 \\
\pm 11\end{array}$ \\
\hline S16 & $\begin{array}{l}28.56 \pm \\
0.03\end{array}$ & $\begin{array}{l}1.35 \pm \\
0.01\end{array}$ & $\begin{array}{l}38.88 \pm \\
0.04\end{array}$ & $\begin{array}{l}33.12 \pm \\
0.89\end{array}$ & $\begin{array}{l}3.14 \pm \\
0.13\end{array}$ & $\begin{array}{l}30867 \pm \\
154\end{array}$ & $\begin{array}{l}515.30 \pm \\
3.09\end{array}$ & $\begin{array}{l}77.52 \pm \\
0.31\end{array}$ & $\begin{array}{l}832 \pm \\
13\end{array}$ & $\begin{array}{l}13612 \pm \\
41\end{array}$ & $\begin{array}{l}11841 \pm \\
249\end{array}$ & $\begin{array}{l}4873 \\
\pm 29\end{array}$ \\
\hline S17 & $\begin{array}{l}26.52 \pm \\
0.03\end{array}$ & $\begin{array}{l}0.80 \pm \\
0.02\end{array}$ & $\begin{array}{l}39.93 \pm \\
0.96\end{array}$ & $\begin{array}{l}32.79 \pm \\
0.33\end{array}$ & $\begin{array}{l}3.33 \pm \\
0.08\end{array}$ & $\begin{array}{l}29815 \pm \\
149\end{array}$ & $\begin{array}{l}513.73 \pm \\
4.62\end{array}$ & $\begin{array}{l}78.54 \pm \\
0.08\end{array}$ & $\begin{array}{l}680 \pm \\
3\end{array}$ & $\begin{array}{l}14048 \pm \\
183\end{array}$ & $\begin{array}{l}7782 \pm \\
16\end{array}$ & $\begin{array}{l}5877 \\
\pm \\
6\end{array}$ \\
\hline $\mathrm{S} 18$ & $\begin{array}{l}27.02 \pm \\
0.49\end{array}$ & $\begin{array}{l}0.75 \pm \\
0.01\end{array}$ & $\begin{array}{l}40.13 \pm \\
0.80\end{array}$ & $\begin{array}{l}32.97 \pm \\
0.30\end{array}$ & $\begin{array}{l}3.96 \pm \\
0.06\end{array}$ & $\begin{array}{l}37900 \pm \\
190\end{array}$ & $\begin{array}{l}554.54 \pm \\
1.11\end{array}$ & $\begin{array}{l}77.39 \pm \\
0.70\end{array}$ & $\begin{array}{l}846 \pm \\
14\end{array}$ & $\begin{array}{l}14907 \pm \\
89\end{array}$ & $\begin{array}{l}16373 \pm \\
49\end{array}$ & $\begin{array}{l}5539 \\
\pm 44\end{array}$ \\
\hline S19 & $\begin{array}{l}27.15 \pm \\
0.08\end{array}$ & $\begin{array}{l}0.78 \pm \\
0.01\end{array}$ & $\begin{array}{l}36.07 \pm \\
0.11\end{array}$ & $\begin{array}{l}34.63 \pm \\
1.66\end{array}$ & $\begin{array}{l}2.89 \pm \\
0.05\end{array}$ & $\begin{array}{l}31830 \pm \\
159\end{array}$ & $\begin{array}{l}388.73 \pm \\
0.39\end{array}$ & $\begin{array}{l}78.23 \pm \\
0.47\end{array}$ & $\begin{array}{l}490 \pm \\
18\end{array}$ & $\begin{array}{l}14740 \pm \\
88\end{array}$ & $\begin{array}{l}20469 \pm \\
123\end{array}$ & $\begin{array}{l}5455 \\
\pm 27\end{array}$ \\
\hline $\mathrm{S} 20$ & $\begin{array}{l}27.50 \pm \\
0.39\end{array}$ & $\begin{array}{l}0.85 \pm \\
0.01\end{array}$ & $\begin{array}{l}38.20 \pm \\
0.46\end{array}$ & $\begin{array}{l}35.52 \pm \\
0.14\end{array}$ & $\begin{array}{l}3.94 \pm \\
0.07\end{array}$ & $\begin{array}{l}31310 \pm \\
157\end{array}$ & $\begin{array}{l}534.27 \pm \\
2.67\end{array}$ & $\begin{array}{l}81.14 \pm \\
1.05\end{array}$ & $\begin{array}{l}375 \pm \\
12\end{array}$ & $\begin{array}{l}12979 \pm \\
65\end{array}$ & $\begin{array}{l}8787 \pm \\
70\end{array}$ & $\begin{array}{l}5977 \\
\pm 24\end{array}$ \\
\hline Minimum & 19 & 0.75 & 32.11 & 29.08 & 2.23 & 20240 & 312.83 & 63.25 & 326 & 11646 & 1485 & 3913 \\
\hline Maximum & 31.61 & 2.35 & 49.45 & 36.93 & 4.09 & 40481 & 572.85 & 84.08 & 4265 & 26550 & 75496 & 6677 \\
\hline Mean & $\begin{array}{l}26.58 \pm \\
0.50\end{array}$ & $\begin{array}{l}1.37 \pm \\
0.02\end{array}$ & $\begin{array}{l}40.11 \pm \\
0.43\end{array}$ & $\begin{array}{l}33.70 \pm \\
0.88\end{array}$ & $\begin{array}{l}3.30 \pm \\
0.06\end{array}$ & $\begin{array}{l}30255 \pm \\
151\end{array}$ & $\begin{array}{l}476.64 \pm \\
3.0\end{array}$ & $\begin{array}{l}74.4 \pm \\
0.55\end{array}$ & $\begin{array}{l}1507.8 \\
\pm 18\end{array}$ & $\begin{array}{l}14311 \pm \\
98.8\end{array}$ & $\begin{array}{l}11269 \pm \\
74\end{array}$ & $\begin{array}{l}4998 \\
\pm 31\end{array}$ \\
\hline $\begin{array}{l}\text { Earth's crust }{ }^{\mathrm{a}} \text {, } \\
(\mathrm{mg} / \mathrm{kg})\end{array}$ & 17 & 0.102 & 35 & 14.3 & 2 & 30890 & 527 & 52 & 29450 & 13510 & 25670 & 28650 \\
\hline
\end{tabular}




\begin{tabular}{|c|c|c|c|c|c|c|c|c|c|c|c|c|}
\hline Pasur river $^{\mathrm{b}}$ & $\begin{array}{l}21.9 \sim \\
33.6\end{array}$ & $\begin{array}{l}1.33 \sim \\
2.10\end{array}$ & $\begin{array}{l}44.9 \sim \\
57.7\end{array}$ & & $\begin{array}{l}8.87 \sim \\
12.4\end{array}$ & - & - & - & - & - & - & - \\
\hline $\begin{array}{l}\text { Brahmaputra } \\
\text { river }^{c}\end{array}$ & 7.6 & 0.48 & 6.6 & 6.2 & - & - & 126.2 & 52.7 & - & - & - & - \\
\hline
\end{tabular}

Note: ${ }^{a}$ The reference values of all the studied metals in Earth's crust (Hans Wedepohl, 1995). ${ }^{\text {b}}$ Reference values of heavy metals detected in sediments of Pasur River (Ali et al., 2018b) for comparison with the present study; ${ }^{C}$ Reference values of heavy metals detected in sediments of Brahmaputra River (Bhuyan et al., 2019) for comparisons with the present study.

Table 6. Sediment Quality Guideline values and total toxicity score of heavy metals

\begin{tabular}{|llllll|}
\hline $\begin{array}{l}\text { Studied Metals } \\
\text { in Sela river sediments }\end{array}$ & \multicolumn{3}{c}{ Sediment Quality Guideline values } & \multirow{2}{*}{ Total Score $^{\mathrm{c}}$} \\
\cline { 2 - 5 } $\mathrm{Pb}$ & 46.7 & 218 & 35 & 91.3 & 1531 \\
\hline $\mathrm{Cd}$ & 1.2 & 9.6 & 0.596 & 3.53 & 1320 \\
\hline $\mathrm{Cr}$ & 81 & 370 & 37.3 & 90 & 895 \\
\hline $\mathrm{Co}$ & - & - & - & - & 1013 \\
\hline $\mathrm{Cu}$ & 34 & 270 & 35.7 & 197 & 807 \\
\hline $\mathrm{Ni}$ & - & - & - & - & 996 \\
\hline $\mathrm{As}$ & 8.2 & 70 & 5.9 & 17 & 1674 \\
\hline $\mathrm{Hg}$ & - & - & - & - & 1458 \\
\hline $\mathrm{Fe}$ & - & - & $20000^{\mathrm{c}}$ & $40000^{\mathrm{c}}$ & - \\
\hline $\mathrm{Mn}$ & - & - & $460^{\mathrm{c}}$ & $1100^{\mathrm{c}}$ & 798 \\
\hline $\mathrm{Zn}$ & 150 & 410 & 123 & 315 & 915 \\
\hline
\end{tabular}

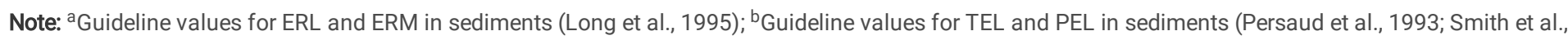
1996); cThe total score of metals according to the hazardous list (2015).

Table 7. Principal component loadings (varimax normalized) of selected metals in water and sediment samples collected from Sela River, Bangladesh.

\begin{tabular}{|c|c|c|c|c|c|c|c|}
\hline \multirow{2}{*}{$\begin{array}{l}\text { Name of } \\
\text { element }\end{array}$} & \multicolumn{3}{|c|}{ (a) Component for water } & \multirow{2}{*}{$\begin{array}{l}\text { Name of } \\
\text { element }\end{array}$} & \multicolumn{3}{|c|}{ (b) Component for sediment } \\
\hline & 1 & 2 & 3 & & 1 & 2 & 3 \\
\hline $\mathrm{Pb}$ & 0.151 & 0.894 & 0.013 & $\mathrm{~Pb}$ & 0.55 & 0.582 & 0.688 \\
\hline $\mathrm{Cd}$ & 0.669 & 0.715 & 0.018 & $\mathrm{Cd}$ & -0.055 & 0.017 & 0.951 \\
\hline $\mathrm{Cr}$ & 0.909 & -0.259 & -0.02 & $\mathrm{Cr}$ & 0.867 & -0.279 & -0.016 \\
\hline Co & 0.713 & 0.307 & -0.166 & $\mathrm{Mn}$ & 0.904 & -0.052 & -0.143 \\
\hline $\mathrm{Cu}$ & 0.238 & 0.034 & 0.955 & $\mathrm{Cu}$ & 0.859 & 0.034 & 0.089 \\
\hline $\mathrm{Ni}$ & 0.905 & 0.345 & -0.078 & $\mathrm{Fe}$ & 0.688 & 0.517 & -0.329 \\
\hline $\mathrm{Fe}$ & 0.845 & 0.167 & -0.022 & $\mathrm{Zn}$ & 0.718 & 0.603 & -0.207 \\
\hline $\mathrm{Mn}$ & -0.123 & 0.176 & 0.941 & As & 0.72 & 0.495 & -0.023 \\
\hline $\mathrm{Zn}$ & 0.948 & 0.113 & 0.097 & $\mathrm{Ca}$ & -0.119 & -0.781 & 0.239 \\
\hline $\mathrm{Ca}$ & 0.985 & 0.048 & 0.086 & $\mathrm{Mg}$ & -0.177 & 0.823 & 0.281 \\
\hline $\mathrm{Mg}$ & 0.986 & 0.028 & 0.069 & $\mathrm{Na}$ & -0.199 & 0.873 & 0.255 \\
\hline $\mathrm{Na}$ & 0.124 & -0.681 & -0.394 & $\mathrm{~K}$ & 0.565 & 0.472 & -0.279 \\
\hline K & 0.972 & 0.049 & 0.126 & & & & \\
\hline Eigen values & 7.49 & 2.322 & 1.553 & Eigen Value & 5.399 & 2.875 & 1.48 \\
\hline Variance $\%$ & 57.613 & 17.863 & 11.949 & Variance $\%$ & 44.995 & 23.98 & 12.33 \\
\hline Cumulative \% & 57.613 & 75.475 & 87.424 & Cumulative \% & 44.995 & 68.955 & 81.255 \\
\hline
\end{tabular}


Table 8. Pearson correlation coefficient matrix between metals in water and sediment samples in the study area

\begin{tabular}{|c|c|c|c|c|c|c|c|c|c|c|c|c|}
\hline Element & $\mathrm{Pb}$ & $\mathrm{Cd}$ & $\mathrm{Cr}$ & $\mathrm{Cu}$ & $\mathrm{Ni}$ & $\mathrm{Fe}$ & $\mathrm{Mn}$ & $\mathrm{Zn}$ & $\mathrm{Ca}$ & $\mathrm{Mg}$ & $\mathrm{Na}$ & $\mathrm{K}$ \\
\hline \multicolumn{13}{|c|}{ (a) Water samples } \\
\hline $\mathrm{Pb}$ & 1 & & & & & & & & & & & \\
\hline $\mathrm{Cd}$ & $.768^{\star *}$ & 1 & & & & & & & & & & \\
\hline $\mathrm{Cr}$ & -.029 & .386 & 1 & & & & & & & & & \\
\hline $\mathrm{Cu}$ & .123 & .211 & .190 & 1 & & & & & & & & \\
\hline $\mathrm{Ni}$ & .501 & $.857^{\star \star}$ & $.779^{\star *}$ & .165 & 1 & & & & & & & \\
\hline $\mathrm{Fe}$ & .125 & .629 & $.677^{*}$ & .134 & $.738^{\star}$ & 1 & & & & & & \\
\hline $\mathrm{Mn}$ & .170 & .081 & -.171 & $.869^{\star *}$ & -.095 & -.176 & 1 & & & & & \\
\hline Zn & .199 & $.731^{*}$ & $.784^{\star *}$ & .292 & $.849^{\star *}$ & $.895^{\star \star}$ & -.025 & 1 & & & & \\
\hline $\mathrm{Ca}$ & .202 & $.696^{*}$ & $.883^{\star *}$ & .323 & $.895^{\star \star}$ & $.850^{\star \star}$ & -.063 & $.961^{* *}$ & 1 & & & \\
\hline $\mathrm{Mg}$ & .199 & $.686^{*}$ & $.903^{\star \star}$ & .316 & $.914^{\star \star}$ & $.774^{\star \star}$ & -.029 & $.913^{\star \star}$ & $.971^{\star \star}$ & 1 & & \\
\hline $\mathrm{Na}$ & -.402 & -.319 & .294 & -.308 & -.016 & -.265 & -.406 & -.055 & .035 & .129 & 1 & \\
\hline $\mathrm{K}$ & .206 & $.699^{\star}$ & $.837^{\star *}$ & .362 & $.870^{\star \star}$ & $.859^{\star \star}$ & -.023 & $.961^{* *}$ & $.985^{\star *}$ & $.951^{\star *}$ & .044 & 1 \\
\hline Element & $\mathrm{Pb}$ & $\mathrm{Cd}$ & $\mathrm{Cr}$ & $\mathrm{Mn}$ & $\mathrm{Cu}$ & $\mathrm{Fe}$ & $\mathrm{Zn}$ & As & $\mathrm{Ca}$ & $\mathrm{Mg}$ & $\mathrm{Na}$ & $\mathrm{K}$ \\
\hline \multicolumn{13}{|c|}{ (b) Sediment samples } \\
\hline $\mathrm{Pb}$ & 1 & & & & & & & & & & & \\
\hline $\mathrm{Cd}$ & $.501^{*}$ & 1 & & & & & & & & & & \\
\hline $\mathrm{Cr}$ & .233 & -.083 & 1 & & & & & & & & & \\
\hline $\mathrm{Mn}$ & .376 & -.236 & $.755^{\star \star}$ & 1 & & & & & & & & \\
\hline $\mathrm{Cu}$ & $.469^{*}$ & -.031 & $.716^{\star \star}$ & $.700^{\star \star}$ & 1 & & & & & & & \\
\hline $\mathrm{Fe}$ & $.491^{*}$ & -.219 & .324 & .406 & .238 & 1 & & & & & & \\
\hline Zn & $.675^{\star \star}$ & -.234 & .401 & $.667^{\star *}$ & $.664^{\star \star}$ & $.654^{\star \star}$ & 1 & & & & & \\
\hline As & $.613^{\star *}$ & -.079 & $.473^{*}$ & $.670^{\star *}$ & $.577^{\star \star}$ & $.560^{*}$ & $.744^{\star \star}$ & 1 & & & & \\
\hline $\mathrm{Ca}$ & $-.472^{*}$ & .124 & .168 & -.005 & -.163 & $-.484^{\star}$ & $-.648^{\star \star}$ & -.435 & 1 & & & \\
\hline $\mathrm{Mg}$ & .394 & .187 & -.289 & -.167 & -.065 & .193 & .284 & .308 & -.363 & 1 & & \\
\hline $\mathrm{Na}$ & .427 & .173 & -.361 & -.203 & -.055 & .177 & .317 & .307 & $-.468^{*}$ & $.964^{\star \star}$ & 1 & \\
\hline K & $.609^{\star *}$ & -.266 & .321 & $.469^{*}$ & $.464^{*}$ & $.751^{\star \star}$ & $.892^{\star *}$ & $.735^{\star *}$ & $-.672^{* *}$ & .393 & .432 & 1 \\
\hline
\end{tabular}

*. Correlation is significant at the 0.05 level (2-tailed).

**. Correlation is significant at the 0.01 level (2-tailed).

\section{Figures}




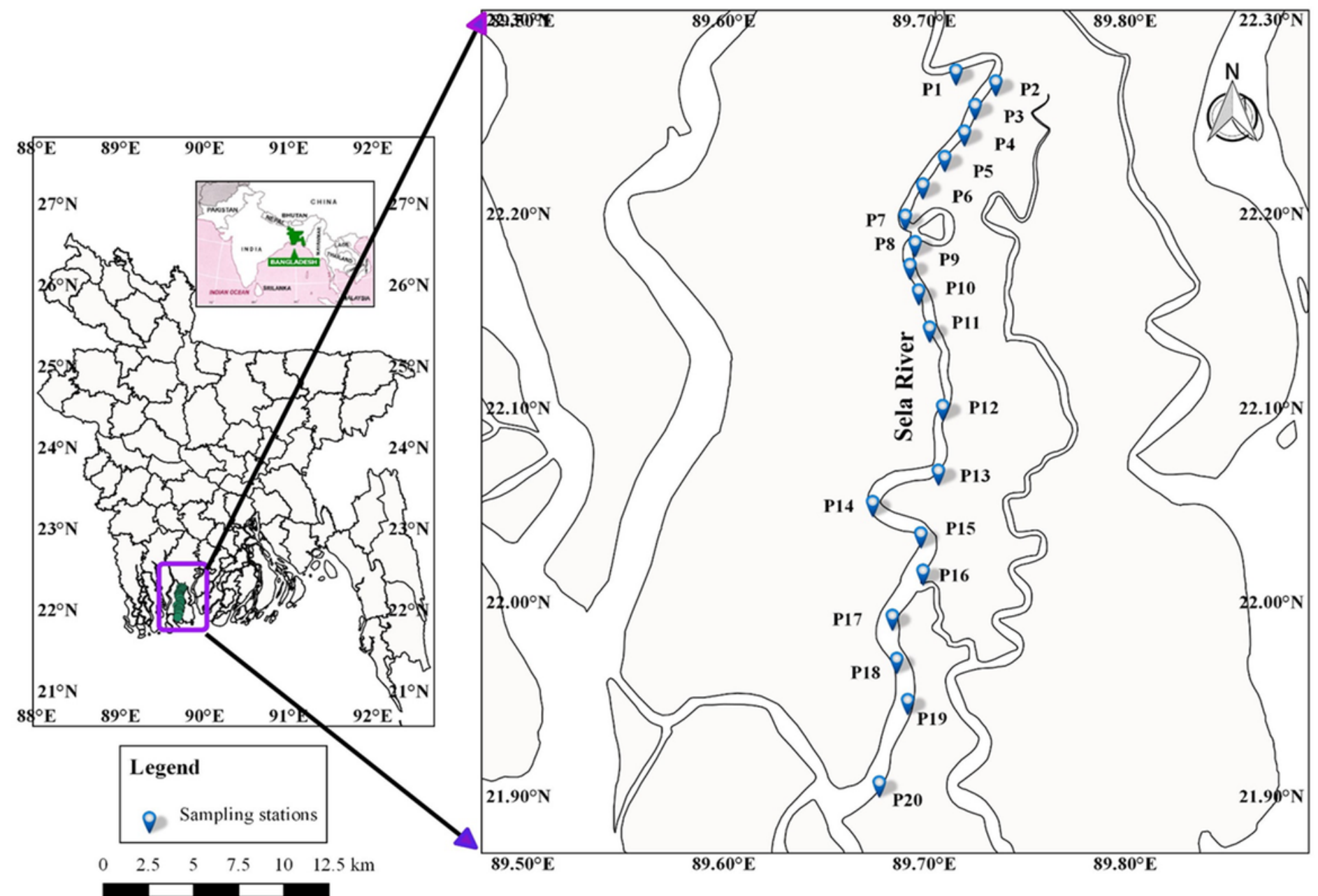

Figure 1

Sampling points (P) using GPS reading in the study area (Sela River, Sundarbans area, Khulna Division, Bangladesh). Note: The designations employed and the presentation of the material on this map do not imply the expression of any opinion whatsoever on the part of Research Square concerning the legal status of any country, territory, city or area or of its authorities, or concerning the delimitation of its frontiers or boundaries. This map has been provided by the authors.
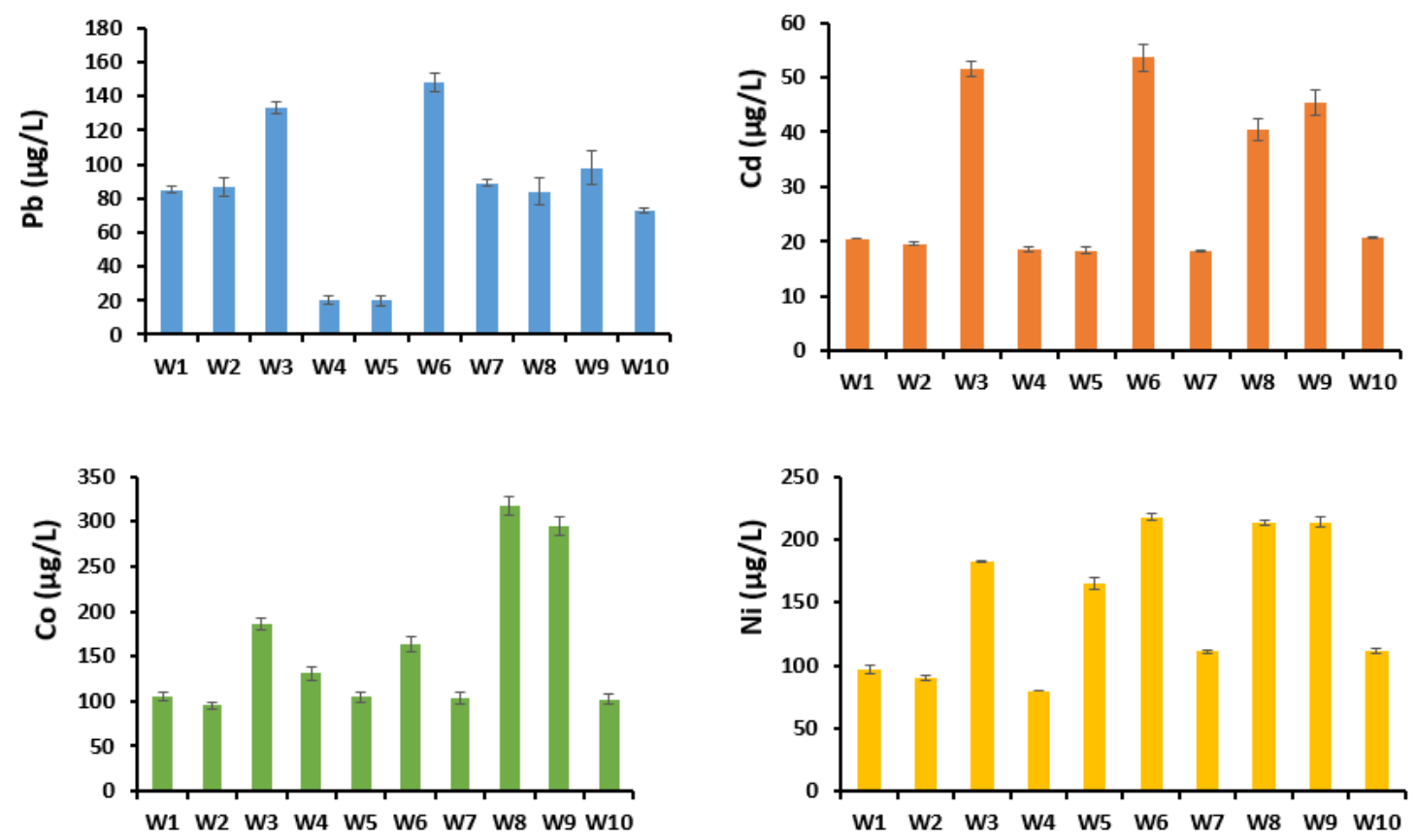
Figure 2

Concentration of $\mathrm{Pb}, \mathrm{Co}, \mathrm{Cd}$ and $\mathrm{Ni}$ in water samples collected from 10 different sampling spots in Sela River, Sundarbans mangrove forest

a)

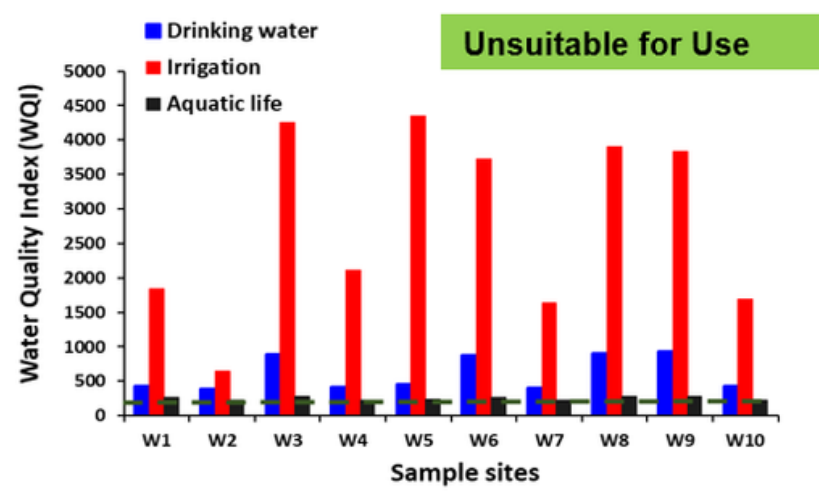

c)

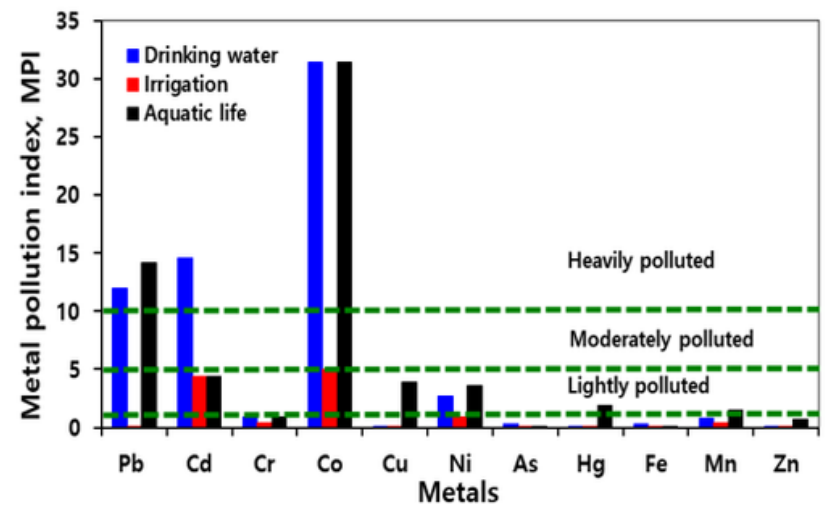

b)

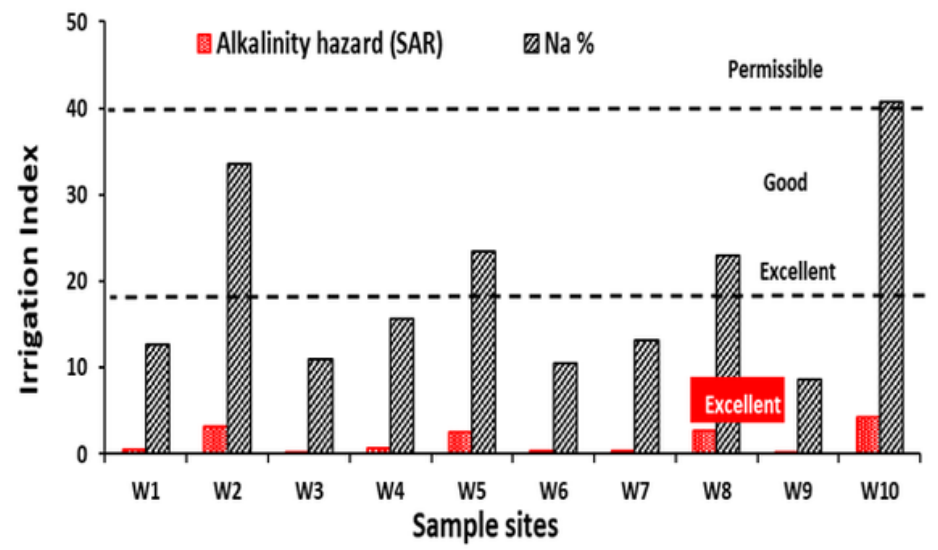

d)

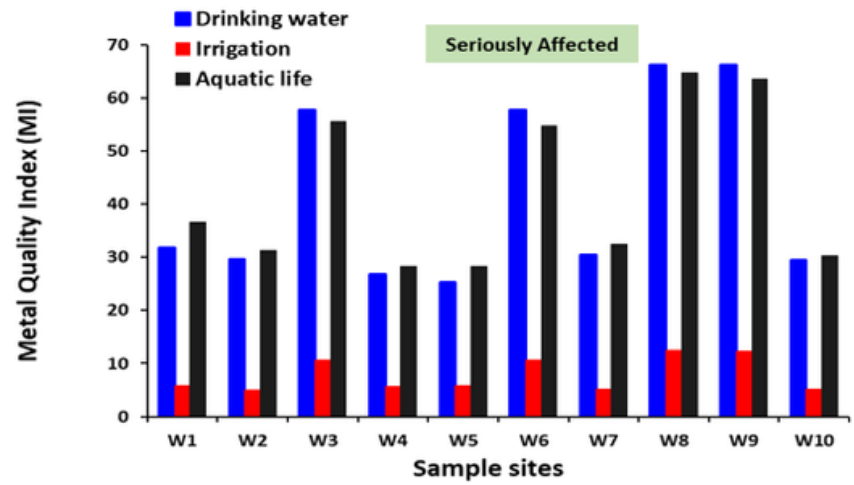

Figure 3

(a) Water quality Index (WQI), (b) irrigation index, (c) Metal Pollution Index (MPI), and (d) Metal Quality Index(MI) in 10 different sampling points in Sela River, Sundarbans mangrove. 
a)

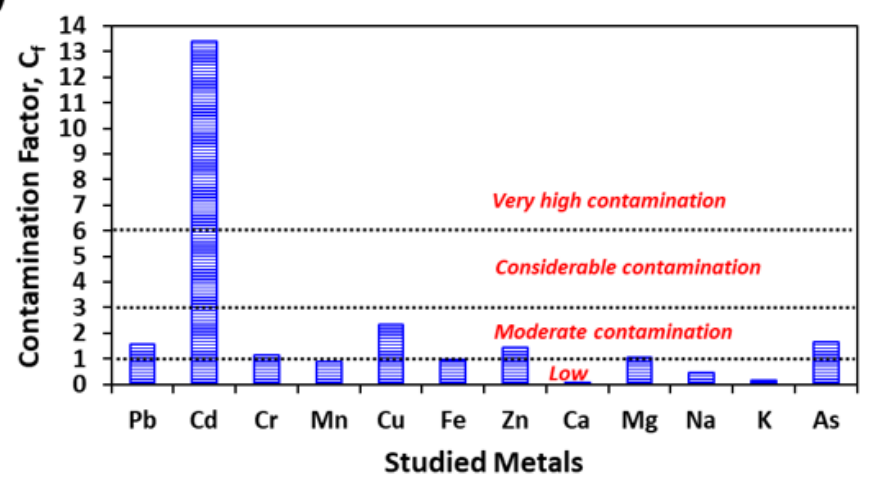

c)

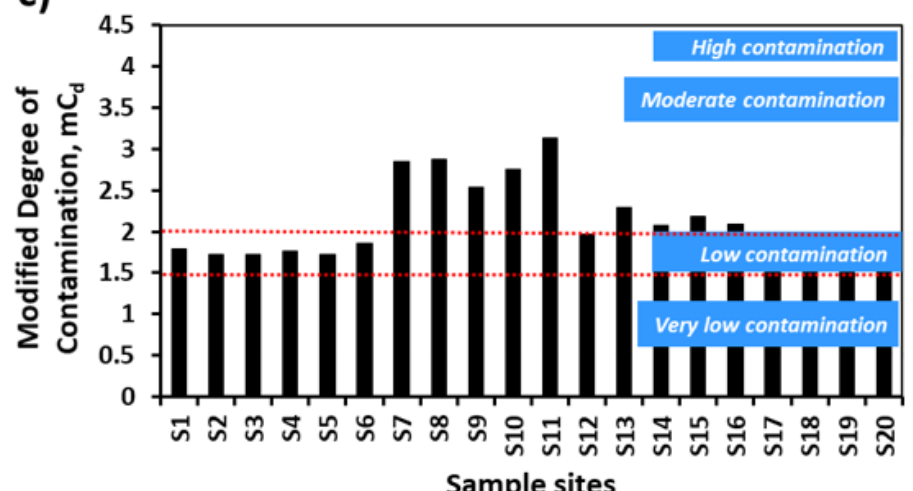

b)

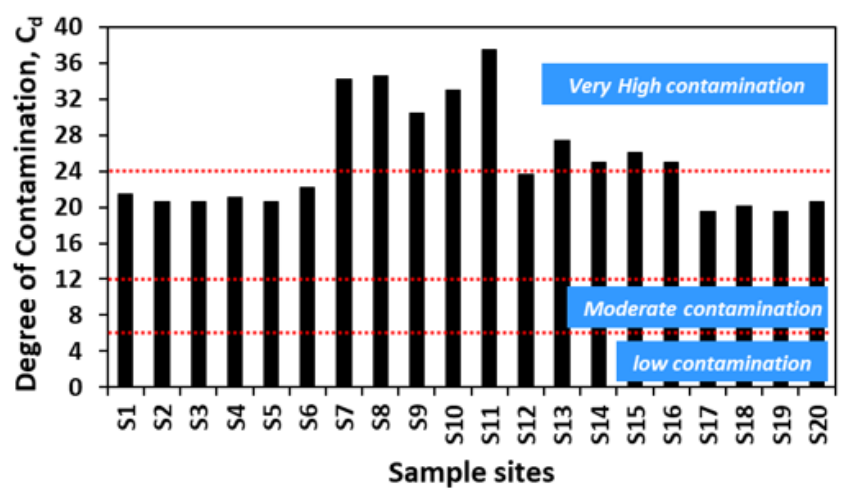

d)

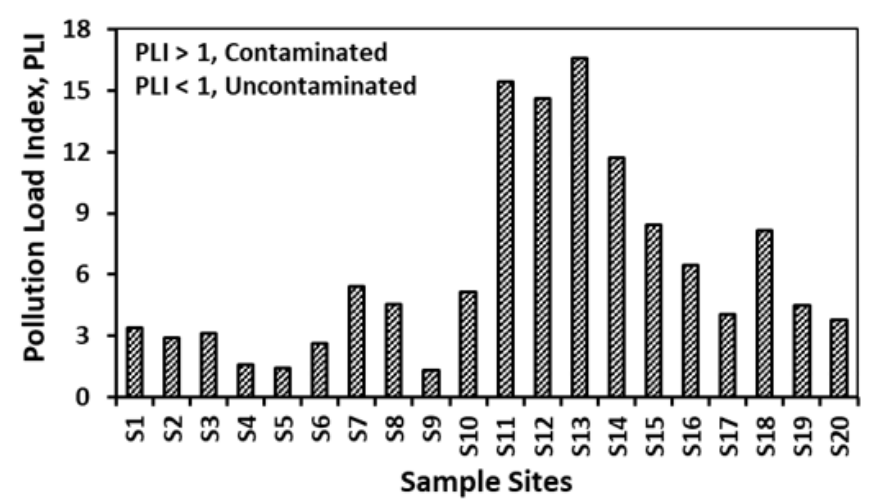

Figure 4

Assessment of sediment quality using different indexes (a) contamination factor, (b) degree of contamination, (c) Modified degree of contamination and Pollution load index from 20 different sampling spots in Sela River, Shundorban, Bangladesh. 
a)
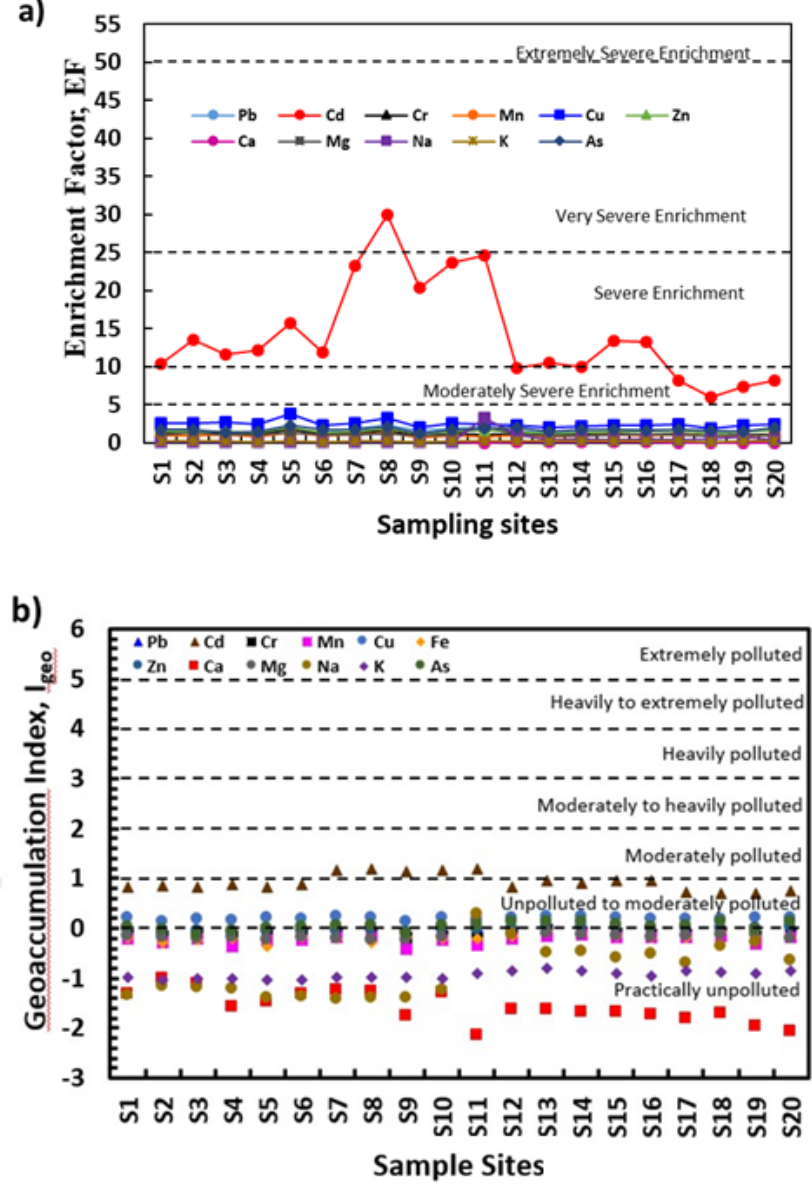

Figure 5

(a) Enrichment Factor (EF) and (b) Geoaccumulation Index (Igeo) of sediment from 20 different sampling spots in Sela River 
a)

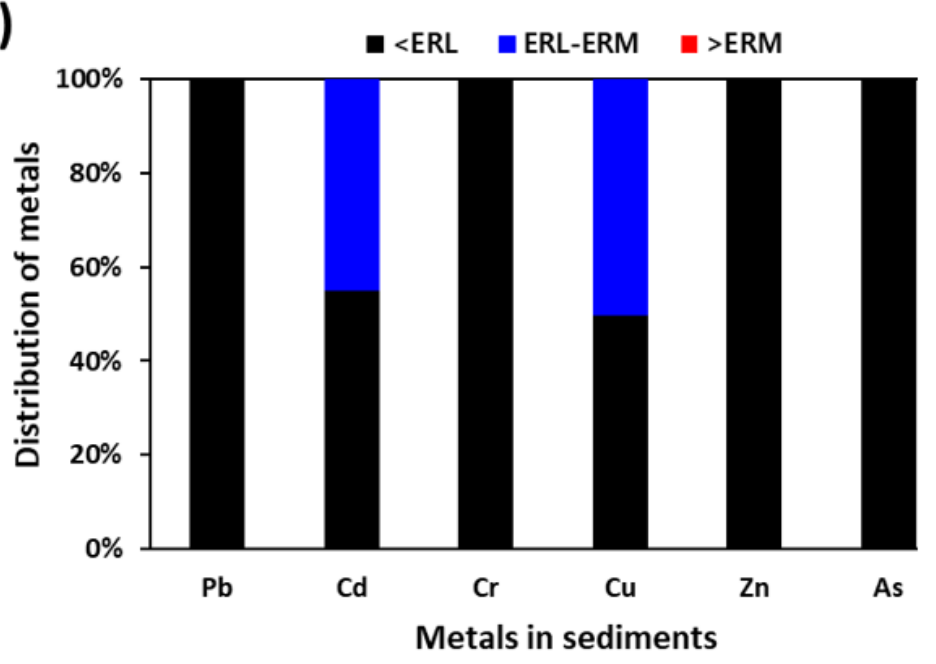

b)

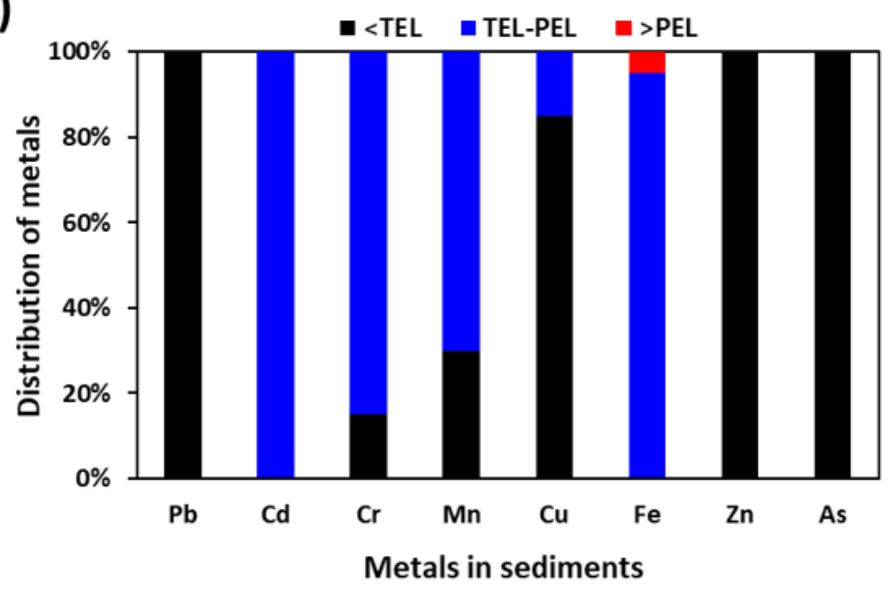

c)

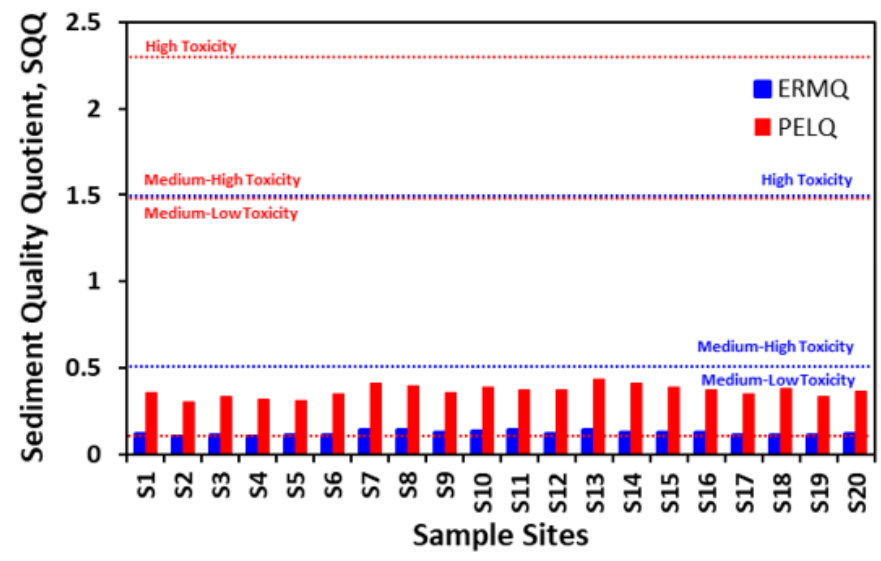

d)

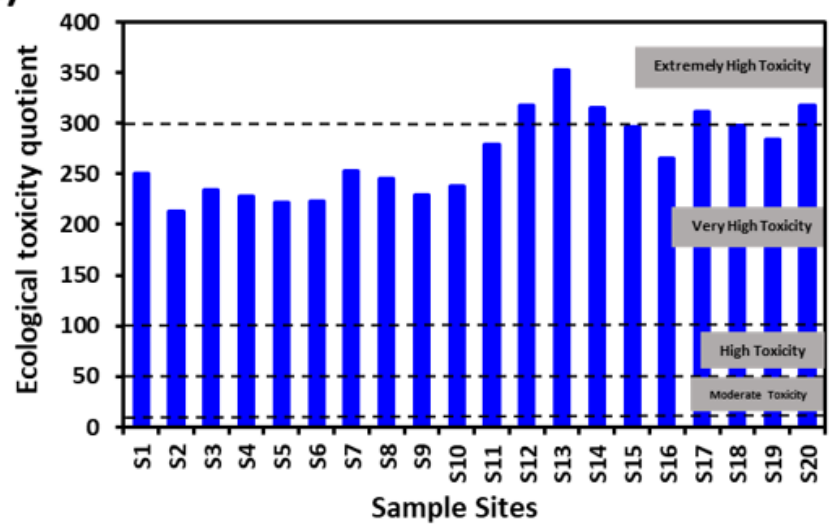

Figure 6

Characterization of Sela River sites with respect to ERL/TEL/PEL, ERMQ/PELQ and ETQ

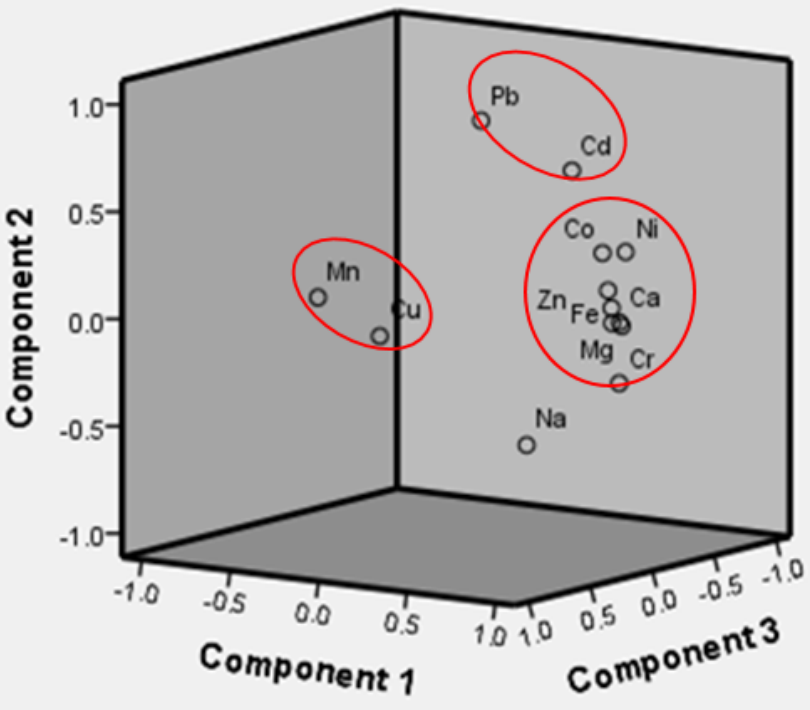

(a) Water

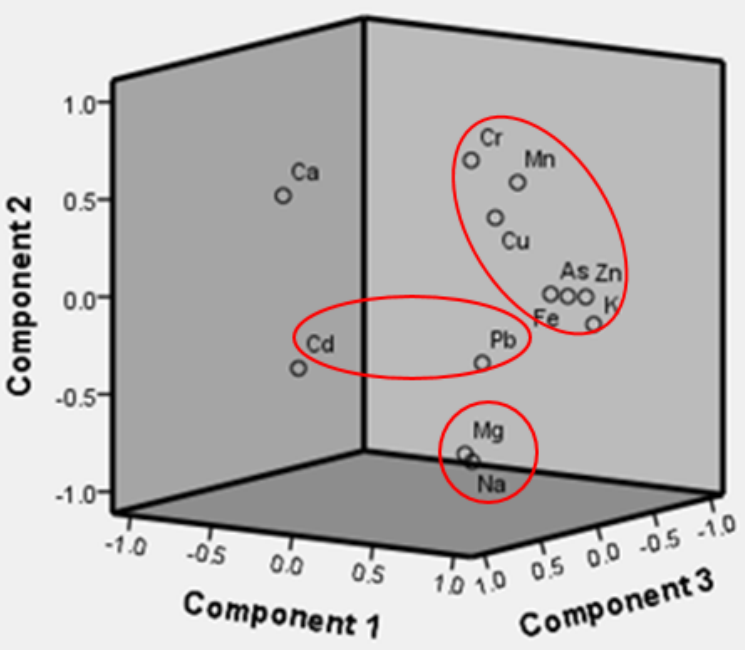

(b) Sediment

Figure 7 


\section{Supplementary Files}

This is a list of supplementary files associated with this preprint. Click to download.

- SupplementaryInformationSelaRiver.docx 